Okul Müdürlerinin Yönetsel Güçlülükleri ile Örgütsel Bağlılıkları Arasındaki İlişkinin İncelenmesi ${ }^{1}$

Examining the Relationship Between Managerial Resourcefulness and Organizational Commitment of School Principals

Yeliz Özkan HIDIROĞLU² $\quad$ Çağlar HIDIROĞLU ${ }^{3} \quad$ Abdurrahman TANRIÖĞREN ${ }^{4}$

Geliş Tarihi

Submitted by

17.10.2017

\title{
Kabul Tarihi
}

Accepted by

01.03.2018

Öz

$\mathrm{Bu}$ araştırmanın amacı okul müdürlerinin yönetsel güçlülükleri ile örgütsel bağl1lıkları arasındaki ilişkinin incelenmesidir. Araştırma nicel araştırmalardan ilişkisel tarama modeli çalışmasıdır. Araştırmanın örneklemi, 20162017 eğitim-öğretim yılında Denizli’nin merkez ilçelerindeki devlet ortaokullarında çalışan 341 öğretmendir. Veriler, "Yönetsel Güçlülük Ölçeği” ve “Örgütsel Bağlılık Ölçeği” aracıllı̆̆ıla elde edilmiştir. Verilerin çözümlenmesinde betimsel, vardamsal, korelasyon, basit ve çoklu regresyon analizi kullanılmıştır. Okul müdürlerinin yönetsel güçlülük düzeyleriyle bilişsel, duyuşsal ve davranışsal boyutlardaki güçlülük düzeyleri yüksektir. Okul müdürleri planlı çalışan, problemlerle baş edebilen, iyi dinleyiciler olarak algılanmaktadır. Müdürlerin nadiren zor-belirgin hedefler belirledikleri, başarısız olmaktan korkmadıkları ve işlerin bitirilmesini zamandan daha fazla önemsedikleri belirlenmiştir. Öğretmenlerin algıları; cinsiyet, kıdem ve branş değişkenlerine göre değişmemekte; okuldaki öğretmen, öğrenci, müdür yardımcısı sayısı ve müdürün okuldaki görev yılına göre değişmektedir. Okul müdürlerinin örgütsel bağl1lıkları ile yönetsel güçlülükleri arasında pozitif yönde yüksek düzeyde ilişki varken; örgütsel bağlılık yönetsel güçlülüğün \%64'ünü yordamaktadır.

\section{Anahtar Sözcükler: Yönetsel Güçlülük • Örgütsel Bağlılık • Okul Müdürü \\ Abstract}

The purpose of this research is to identify the relationship between the managerial resourcefulness and organizational commitment levels of school principals according to teachers' views. This research study is a quantitative research and correlational survey method was used for this descriptive study. The sample of this study is composed of 341 secondary school teachers working in Pamukkale and Merkezefendi districts of Denizli during 2016-2017 academic year. The data of this research were collected by "Managerial Resourcefulness Scale" and "Organizational Commitment Scale". The descriptive and inferential statistical techniques including correlation and simple and multiple regression have been employed in order to analyze the data collected.Teachers' perceptions towards principals' managerial resourcefulness levels has been found high both totally and dimensionally. According to teachers' perceptions school principals follow planned processes, are very good listeners and believe that they can cope with the problems they face. It has been determined that school principals are not afraid of being unsuccessful; set difficult and specific goals for teachers from time to time, and are very sensitive for time management especially for completing their assignments. Teachers' perceptions toward the managerial resourcefulness of principals have not been found differentiated by their gender, seniority, and branches ( $>$ >.05). Teachers' perceptions toward the

${ }^{1}$ International Eurasian Educational Research Congress (EJER) 2017 kongresinde sözlü bildiri olarak sunulmuştur.

2 Sorumlu Yazar: Yeliz Özkan Hıdıroğlu, Pamukkale Üniversitesi, Eğitim Fakültesi, Denizli, Türkiye. Eposta: yelizozkan09@gmail.com

3 Çağlar Hıdıroğlu (Dr Öğr. Üyesi), Pamukkale Üniversitesi, Eğitim Fakültesi, Denizli, Türkiye. Eposta: caglarr.naci@gmail.com

4 Abdurrahman Tanrı̈ğren (Prof. Dr.), Pamukkale Üniversitesi, Eğitim Fakültesi, Denizli, Türkiye. Eposta: atogen@gmail.com

Atıf: Hıdıroğlu, Y.Ö., Hıdıroğlu, Ç., \& Tanrı̈ğen, A. (2018). Okul müdürlerinin yönetsel güçlülükleri ile örgütsel bağl1lıkları arasındaki ilişkinin incelenmesi. Ege Eğitim Dergisi / Ege Journal of Education, 19(1), 83-115. Doi: 10.12984/egeefd.344911 
managerial resourcefulness of principals have been found differentiated by the number of teachers, students, vice principals in their school, and the years principal spent in the school. There is a high significant positive relationship between managerial resourcefullness and organizational commitment of school principals according to teachers, and, organizational commitment explains $64 \%$ of the total variance in the managerial resourcefullness.

Keywords: Managerial Resourcefulness • Organizational Commitment • School Principal

\section{Extended Abstract}

\section{Background}

School principals are mainly responsible and authorized person for establishing a quality school culture, creating an effective and efficient teaching-learning environment (Alıç, 1991; Baştepe, 2009), organizing school employees in order to achieve the goals, directing, coordinating, and controlling the activities (Gürsel, 1997). Besides this, school principals play very significant roles for creating effective communication, observing the needs, using the power in proper ways, motivating and supporting the groups, ensuring confidence, and preserving the existing enthusiasm (Sakall1, 2001). The school principals have to cope with the pressures, problems, and difficulties originated from internal and external environment of organization as well as planning, organizing, directing, coordinating, and controlling the process. The adaptation of organizations to the environment depends on their proper administrative reactions to constant, complex and unsteady environmental conditions. It is necessary to have managerial skills besides with managerial knowledge for an effective administration (Doğan ve Şahin, 2011). The necessary skills of the principals for managerial works refers to the concept of managerial resourcefulness (Kanungo ve Misra, 1992). Managerial resourcefulness is a group of specific cognitive, affective, and psychomotor skills which facilitate the proper reaction needed for administrative work (Kanungo ve Menon, 2005). By means of the skills associated with managerial resourcefulness, school principals can decide on when and how to employ their skills. Managerial resourcefulness as a component of effective administration and leadership is very important for organizations. The administrators who have high level of managerial resourcefulness can show the skills of controlling and organizing of their feelings, thoughts, and behaviors when fulfilling their roles and functions (Kanungo ve Menon, 2004; 2005).

\section{Purpose}

The managerial resourcefulness of school principals, who are very important component of school culture, is very significant in developing school culture and its functioning. The purpose of this research is to: identify the managerial resourcefulness levels of school principals by teachers' perceptions and to explain the relationships between these perceptions and selected independent variables; relationship between school principals commitment to the school and their managerial resourcefullness. In order to obtain more unbiased results, this study was carried out with teachers who were working in the same settings. Since there are very limited studies in national literature related to managerial resourcefulness, this study is expcted to provide very significant contribution to the field of educational administration. In this study, it is aimed to examine the relationship between school principals' organizational commitment and their managerial resourcefullness. The following sub-problems have been developed for this study:

1) What is the managerial resourcefulness levels of school principals according to teachers' perceptions? 
2) What is the managerial resourcefulness levels of school principals in cognitive, affective and psychomotor dimensions according to teachers’ perceptions?

3) Do teachers' perceptions towards total and dimentional (cognitive, affective, psychomotor) managerial resourcefulness levels differ according to the following independent variables?: (a) gender, (b) seniority, (c) branch, (d) the number of assistant principal, (e) number of teachers, (f) number of students, (g) principal's serving years in the same school.

4) According to the teachers' perception, what is the relationship between the managerial resourcefullness of school principals and their organizational commitment?

5) According to the teachers' perception, what is the relationship between the dimensions of managerial resourcefullness' for school principals and their organizational commitment's dimensions?

6) According to teachers' perceptions, how do organizational commitment of school principals predict their managerial resourcefullness?

7) According to teachers' perceptions, how do organizational commitment's dimensions of school principals predict their managerial resourcefullness’ dimensions?

\section{Method}

This research study is a quantitative research and correlational survey method was used for this descriptive study. Correlational survey method is a research method that is aimed at determining the presence or degree of relation between two or more variables (Karasar 1998). The SPSS 23 statristical analysis program was used to analyze the data. The study was designed as a correlational research and it was aimed to determine first whether there is a correlation between variables, and as certain the direction, form and degree of this relationship between variables if there is a correlation. In the study, Pearson correlation, simple linear regression, and multiple regression analyzes were used. The population of this study is composed of 2719 teachers working for Pamukkale (1271) and Merkezefendi (1448) districts of Denizli during 2016-2017 academic year. The sample has been selected by simple random sampling method and by considering Gay and Airasan's (1996) sampling table as 338 teachers. This study has been carried out with 341 secondary school teachers working for 26 different schools. The data of this research has been collected by “Managerial Resourcefulness Scale” developed by Kanungo ve Menon (2004, 2005) and adapted to Turkish by Şahin (2009) and Balay’s (2000) organizational Commitment Scale. Managerial resourcelfullness scale has three dimensions such as cognitive, affective and psycho-motor. Seven academicians studying in the field of Educational Sciences were consulted in order to ensure the content validity of the scale, and a pilot study was carried out. The exploratory and confirming factor analysis have been applied in order to ensure the construct validity of the scale. Thirtyeight responses, which were filled out improperly, were excluded. The reliability coefficients have been calculated for managerial, cognitive, affective and psycho-motor resourcefulness as .97, .94, .88, and .93 respectively. The "Organizational Commitment Scale" developed by Balay (2000), consisted three dimensions: compliance, identification, and internalization ona 5-point Likert-type scale. The scale was adapted to 
determine the perceptions of teachers about the organizational commitment of the school principals in line with the aim of the study. In addition, based on the experts' opinions, "I agree at the moderate level" section was removed, and the scale was applied as a 4-point Likert-type scale. The opinions and suggestions of seven experts from Educational Sciences Department were consulted, and pilot study was conducted to ensure content validity of the scale. Explanatory and confirmatory factor analyzes were performed to ensure construct validity of the scale. The adapted scale also consists of 27 items and 3 dimensions (cohesion, identification and internalization). The first 8 items of scale are the reversing entries. The Organizational Commitment Scale was analyzed on the basis of dimensions and according to dimensions; Cronbach Alpha internal consistency coefficients were calculated as ÖBUyum = .76, ÖBÖz $==.91$, ÖB $=.96$ and the total reliability of the scale ÖB total $=.95$. The percentages and frequencies have been calculated for explaining and describing the demographic characteristics of sample. Descriptive analyses(percentages, frequencies, mean etc.) were used for determining and interpreting the teachers' perceptions (first and second sub-problems) toward the managerial resourcefulness(with its dimensions) of school principals. Before running the analysis for third sub-problem, the scores calculated were subjected to Kolmogorov Smirnov test in order to test the assumption of normality.. According to the test results cognitive dimension $(K S z=1,465 ; \mathrm{p}>.05)$ and affective dimension $(K S z=1,153 ; \mathrm{p}>.05)$ were found normally distributed, while psycho-motor dimension $(\mathrm{KSz}=1.76 ; \mathrm{p}<.05)$ was not. Pearson Correlation analysis was ranto determine the relationship between school principals' managerial resourcefullness and organizational commitment (4th sub-problem), and the relationship between school principal's managerial resourcefullness dimensions and organizational commitment dimensions (5th sub-problem). Correlation coefficient alues are interpreted as follows; $0.00<\mathrm{r}<0.25$ very weak relationship, $0.26<\mathrm{r}<0.49$ weak relationship, $0.50<\mathrm{r}<0.69$ moderate relationship, $0.70<\mathrm{r}<0.89$ high level relationship, $0.90<\mathrm{r}<1.00$ very high level relationship (Kalayc1, 2016 ). Simple linear regression was used to find out how the organizational commitment of school principals predicted their managerial resourcefullness (6th problem). Simple linear regression was used to find out how the dimensions of school principals' organizational commitment predicted their managerial resourcefullness’s dimensions (7th problem).

\section{Findings}

Teachers' perceptions towards principals' managerial resourcefulness levels has been found high both totally and dimensionally (MR Cognitive: 3.84; MR Affective: 3.59; MR Psycho-motor: 3.79; MR Total: 3.74). According to this findings, teachers believe that school principals have high level of cognitive, affective, and psycho-motor managerial resourcefulness. According to teachers' perceptions, school principals follow planned processes, are very good listeners, and believe that they can cope with the problems when they face them. It has ben determined that school principals are not afraid of being unsuccessful; determine difficult and specific goals for their teachers from time to time, and are very sensitive for time management especially for completing their assignments. Teachers’ perceptions toward the managerial resourcefulness of principals have not been found differentiated by their gender, school graduated, unions, in-service training, managerial experiences, seniority, age nor thebranches ( $\mathrm{p}>.05)$. Teachers' perceptions toward the managerial resourcefulness of principals have been found differentiated 
by their academic level, school types, the number of teachers, students, vice principals in their school, and the years principal spent in the school $(\mathrm{p}<.05)$. Teachers who had bachelor degree have perceived the managerial resourcefulness of their principals as higher than the teachers who had master's degree (While $M R_{\text {Affective }}$ and $M R_{\text {Psychomotor dimensions and }} \mathrm{MR}_{\text {Total }} \mathrm{p}>.05$; for $\mathrm{MR}_{\text {Cognitive }} \mathrm{p}<.05$ ). Teachers working for middle schools have perceived their principals' managerial resourcefulness higher (While $M R_{\text {Affective }}$ and $M R_{\text {Psychomotor dimensions and }} \mathrm{MR}_{\text {Total }} \mathrm{p}>.05$; for $\mathrm{MR}_{\text {Cognitive }} \mathrm{p}^{<.05}$ ). When teacher perceptions related to principals' managerial resourcefulness were analized according to the number of teachers variable, teachers' perceptions who are working for schools where 41-60 teachers were employed, have been found significantly lower than teachers working for schools where 21-40 teachers and more than 61 teachers were employed (especially for $M R_{\text {Affective }}$ and $M R_{\text {Total }}$ dimensions). Teachers' perceptions who work in schools where 41-60 teachers were employed, towards managerial resourcefulness of principals in $\mathrm{MR}_{\text {Cognitive }}$ and $M R_{\text {Psychomotor }}$ dimensions were found lower than othergroups. When teacher perceptions related to principals' managerial resourcefulness were analized according to the number of students variable, in $\mathrm{MR}_{\text {Affective }}$ dimension teachers' perceptions who work in schools which has 500-1000 students have been calculated lower than other schools. In $\mathrm{MR}_{\text {Cognitive, }} \mathrm{MR}_{\text {Psychomotor }}$ and $\mathrm{MR}_{\text {Total }}$ dimensions, teachers' perceptions who work in schools with less than 500 students were found lower than othergroups. When teacher perceptions related to principals' managerial resourcefulness were analized according to the number of students variable, in $\mathrm{MR}_{\text {Cognitive, }} M R_{\text {Affective, }} \mathrm{MR}_{\text {Psychomotor, }}$ and $\mathrm{MR}_{\text {Total, }}$ teacher perceptions who work for schools where two vice principals serve have been calculated lower than other teachers. When teacher perceptions related to principals' managerial resourcefulness were analized according to "serving year" variable, in $\mathrm{MR}_{\text {Cognitive, }} M R_{\text {Affective, }} \mathrm{MR}_{P_{\text {sychomotor, }} \text { and }} \mathrm{MR}_{\text {Total }}$ dimensions, teachers' perceptions who work between 2 to 4 years in the same school were calculated lower than other teachers. According to teachers' perceptions, the relationship between school principals' sub-dimensions of managerial resourcefullness and their sub-dimensions of organizational commitment was examined. As can be seen in Table 21, there was a significant positive correlations, such as between affective and cognitive strength, which was very high (.91); between emotional and behavioral strength (.88) was high; between cognitive and behavioral strength (.94) was also very high. Respectively identification, internalization, and compliance; can be said to be a significant predictor of managerial resourcefullness $(\mathrm{R}=.798 \mathrm{R} 2=.637)$. According to this; adaptation, internalization, and identification explain $64 \%$ of the total variance in the management resourcefullness.

\section{Conclusions/Discussions and Implications}

School principals' total and dimensional managerial resourcefulness levels have been found high according to teachers perceptions. It shows that school principals can control and organize their emotions, thoughts, and behaviors while carrying out their managerial roles and duties. It also shows that school principals who have high managerial resourcefulness level can achieve a healty school culture and create effective and successful school environments. School principals work with a specific plan and are good listeners. It has been determined that school principals are not afraid of being unsuccessful, designate difficult and specific goals for teachers from time to time, sensitive on time management when it comes 
to task completion. Principals who have a high level of managerial resourcefullness are expected to show fear of being unsuccessful. Furthermore, school principals pay attention to task completion but do not show same sensitivity related to time management. As Drucker (1974) said, if the time can not be managed properly, nothing can be managed properly. For this reason, school principals are expected to have extraordinary time management skills. Goal difficulty and goal specificity effect motivation positively (Getzels \& Guba, 1957). It can be said that school principals should determine achievable and specific objective and adopt these objective to school culture in order to increase the motivation levels of teachers. Teachers' perceptions towards the managerial resourcefulness of the principals did not differ significantly according to the following variables: gender, seniority, serving years in same school, and branch. Just in schools where secondary school education exist, teachers' perception toward the cognitive resourcefulness of principals have been found high than teachers who were working for the schools where both primary and secondary education were provided. A possible explanation is that the principals who work at secondary school level have less difficult and complex tasks. Teachers who are working for the schools where principals have been working for more than four years have higher level of perceptions towards principal's managerial resourcefulness than the other teachers. In this case, these principals have more experiences and knowledge about school problems and, by this means, their managerial resourcefulness could be perceived higher. Teachers who are working for schools where 41-60 teachers are employed have lower perceptions toward managerial resourcefulness of principals than other teachers. Schoools that employ more than 40 teachers have a larger student population and, in this case more manegerial difficulties, problems, and conflicts can be witnessed. It has been seen that at least 3 vice principals helped principals for their manegerial works in the schools where more than 60 teachers work. In the schools with 41-60 teachers there are generally 2 vice principals, and this situation makes it difficult to assist managerial works of principals. In schools where 41-60 teachers employed, teachers' perceptions towards principals' managerial resourcefulness could be low for this reason. The size of organization can create more complicated means and methods for achieving the goals, communication system, and task relations. Teachers in small schools have more positive perceptions related to managerial effectiveness of the principal compared toteachers working for big schools. In small schools principal's control and sanction powers are very high because communication, management and supervision operate more easily and in a healty manner; so, effective behaviors of principals are perceived more positively. We can arguethat in crowded schools, principals can devote limited time for achieving school goals, improving themselves and their organizations, supervising human resources, and therefore more complicated and unhealthy communication settings can be created. Tinaz (2014) claims that moderately significant positive relationship between managerial effectiveness and organizational commitment of administrators and teachers in primary and secondary schools. Karataş (2008) found a relationship between the managerial effectiveness of school principals and their school climate, also found a linear positive relationship between the scores of school principals' managerial skills and the school climate's morale, sincerity, close control, job orientation, and understanding dimensions. Accordingly, Tinaz (2014) and Karataş' (2008) studies support the findings of this study. In future, researches with mixed methods can be carried out related to the managerial resourcefulness of principals

who are working 
for different educational levels (pre-school, primary and high schools) and varying school cultures. Also, a Project can be carried out in order to increase school principals' managerial resourcefulness in cognitive, affective and psycho-motor dimensions through in-service training programs. In the schools where managerial resourcefulness have been calculated high and low, qualitative or mixed studies can be carried out in order to understand its reasons. According to the results obtained, the number of students in our schools should be reduced. When there are 2 vice principals, teachers perceive principals managerial resourcefulness as insufficient. In order to increase the managerial resourcefulness of principals, just one vice principals in small schools and at least 3 vice principals in big schools should be assigned. The schools where both primary and secondary schools exist, it should be transformed into just primary or secondary school. Furthermore, especially school managers and other constituents of school culture should be informed about the results obtained, their opinions can be considered and their managerial resourcefulness levels can be considered as a criteria for principal selection process. 


\section{Giriş}

Küreselleşen ve hızlı teknolojik gelişmelerin yaşandığı dünyada okul müdürleri; sorunları çözmede, sorunların nedenlerini araştırmada, kaynakları en doğru, rasyonel ve bilimsel olarak kullanmada, çalışanların motivasyonlarını sağlamada belirlenen hedeflere ulaşmada sorumluluk sahibidirler. 21. yüzyılın okul yöneticileri, plan yapma, örgütleme, yönlendirme, kontrol ve koordine etmenin yanında, örgütteki baskılar, problemler ve zorluklarla mücadele etmek durumundadırlar. Örgütlerin bulundukları ortama uyum sağlamaları, değişen koşullara uygun yönetimsel tepkiler vermelerine bağlıdır. Başarılı yönetimler için de yönetimsel bilgilerle birlikte yönetimsel beceri ve yetenekler gereklidir (Doğan ve Şahin, 2011). Okul müdürlerinin yönetsel işlerde gerekli olan yetenek ve becerileri yönetsel güçlülük kavramını karşımıza çıkarmaktadır (Kanungo ve Misra, 1992). Yönetimdeki görevlere uygun reaksiyonu sağlayan duyuşsal, bilişsel ve davranışsal beceriler kümesine yönetsel güçlülük denilmektedir (Kanungo ve Menon, 2005; bkz. Tablo 1).

Tablo 1. Yönetsel güçlülüğün bileşenleri ve bu bileşenlere ait yetenekler (Kanungo ve Misra, 1992)

\begin{tabular}{clll}
\hline Bileşenler & Duyuşsal & Bilişsel & Davranışsal \\
\hline & *Duyuşsal denetim & *Problemi Çözme & *Göreve Yönelik Davranma \\
Yetenekler & *Sakinlik & *Özdüşünüm & *Bireye Yönelik Davranma \\
& *Anlık Tatmini Erteleme & & \\
& *Pro-aktif Olma & & \\
\hline
\end{tabular}

Kanungo ve Menon’a (2005) göre, duyuşsal güçlülük; yöneticinin duygusal tepkilerini başarılı bir şekilde düzenleme yeteneğidir ve duygusal kontrolü; sakin olmayı, anlık doyumu ertelemeyi ve proaktif olmayı içermektedir. Duygusal kontrol dört yeteneği gerektirmektedir. Hiyerarşik olarak birincisi duyguları anlamak, değerlendirmek ve ifade etmektir. İkincisi duyguları anlayıp analiz etme ve ifade etmedir, bir başka deyişle "duygusal okuryazarlık" olarak ifade edilebilir. Üçüncüsü duyguları anlayarak akıl yürütmektir. Dördüncüsü ise duyguları kontrol edebilmektir (Goleman; 2005; Mayer, DiPaolo ve Salovey, 1990; Salovey ve Mayer, 1990; Savaşır ve Şahin, 1997). Sakin olma, zorluklarla ve sorunlarla karşılaşıldığında bu sorunları çözmeye hazır halde bulunma yeteneğidir (Goleman, 2005; Mayer, DiaPaolo ve Salovey, 1990; Salovey ve Mayer, 1990). Anlık doyumu erteleme, anlık tepkilerle baş etmek, öz-denetim becerileri ve iradeyi kullanarak dürtü kontrolünü sağlamaktır (Dağ, 1991; Siva, 1991; Urbanski, 2000). Proaktif olma, yöneticinin örgütte var olan şartları iyileştirmek veya yeni bir ortam yaratmak için sorumluluk alması, ortama pasif olarak uyum sağlamak yerine statükoyu sorgulaması, sorumluluk duygusu içerisinde harekete geçmesi, problemlerle yeniden karşılaşmamak için gelecekteki zamanların düşünülmesi veya ilk kez karşılaşılan problemlerle baş etme beceri ve davranışlarıdır (Parker, Williams ve Turner, 2006).

Bilişsel güçlülük; problem çözme ve özdüşünüm yeteneğini kapsamaktadır. Problem çözme, gelişen ve değişen çevre şartlarına uyum sağlamak, bu değişimleri önceden sezmek, gerekli önlemleri alarak tehdit ve tehlike oluşturmaktan çıkarmak, sorunları doğru ve zamanında çözmektir (Heppner ve Krauskopf, 1987; Heppner, 1978; Savaşır ve Şahin, 1997). Özdüşünüm, kendi düşüncelerini gözlemleme, 
bu gözlemler doğrultusunda hareket etme, düşüncelerinin sonuçlarını tahmin edebilme, öz yeterliklerini sınama ve isterlerse değişiklik yoluna gidebilmedir. (Schwarzer, Bäßler, Kwiatek, Schröder ve Zhang, 1997; Schyns ve Collani, 2002).

Davranışsal güçlülük, göreve ve bireye yönelik davranışları içermektedir. Bu sayede okul müdürleri, sahip oldukları becerileri belirleyip uygun zamanda ve ne şekilde kullanacağına karar verebilmektedir. Göreve yönelik davranış, amaç belirleme, plan yapma, uygulama, geri bildirim sürecini içermektedir. Yapılacak işlerin aşamalarının belirlenmesi, ne kadar zamanın gerekli olduğu ve beklenen sonucun ne olduğunun ortaya konmasıdır (Frese, Stewart ve Hannover, 1987; Kanungo ve Misra, 1992). Bireye yönelik davranış, örgütün diğer üyelerinin beklentilerini, inanışlarını, tutum ve davranışlarını ve gereksinimlerini belirlemek için bireysel duyarlılığa sahip olmak diğer bir ifadeyle empatik davranmaktır (Kanungo ve Misra, 1992). Bu doğrultuda yönetsel güçlülüğün, başarılı bir yönetim ve liderliğin önemli bir parçası olduğu düşünülebilir.

Yönetsel güçlülükle ilgili yapılan çalışmalar incelendiğinde, Kanungo ve Misra (1992) beceriler ve yeterlikler arasındaki farkları vurgulamışlardır. Başarılı bir yönetim için gerekli olan yönetsel beceri ve yeteneklerdeki eksiklikleri incelemişlerdir. Kanungo ve Menon (2004) çalışmalarında, yönetsel güçlülükteki üç temel yeterliğin (duygusal, entelektüel ve eylem yönelimli) ölçülebilmesi için ölçek geliştirmişlerdir. Bu ölçeğin, yönetsel güçlülüğü ölçmede ve yöneticilerin eğitimi, yetiştirilmesi ve seçiminde kullanılabilecek geçerli ve güvenilir tanısal bir ölçek olduğunu belirtmişlerdir (Kanungo ve Menon, 2005). Ayrıca yönetsel güçlülük ve yönetsel başarı arasında pozitif yönde anlamlı bir ilişki olduğunu belirtmişlerdir.

Ülkemizde yönetsel güçlülüğe ilişkin yapılan sınırlı sayıdaki çalışmalara bakıldığında, Şahin (2009) doktora çalışmasında yönetsel güçlülüğü Kanungo ve Misra (1992) ve Kanungo ve Menon’un (2004; 2005) bakış açılarıyla ele alarak, yönetimsel işlerin gerektirdiği uygun reaksiyonu sağlayan belirli duyuşsal, bilişsel ve davranışsal yetenek ve beceriler seti olarak tanımlamıştır. Etkili yönetim için yönetsel beceriler ve yeteneklerin gerekli olduğunu söyleyerek, ikisi arasındaki farka değinmiş ve yöneticilerin öğrenme ve sosyalleşmede farklılıklarının yönetsel güçlülüklerinde farklılıklara neden olabileceğini belirtmiştir. Şahin (2009) geliştirdiği 50 maddelik yönetsel güçlülük ölçeğinin toplam varyansın \% 61.45'ini açıklayan 8 faktör yapısına sahip olduğunu bulmuş ve bu sekiz faktörü 3 temel bileşen altında toplanmıştır (bkz. Tablo 1).

Okulların ellerindeki madde ve insan kaynaklarını işler hale getirmek, okulları etkili bir biçimde yönetebilmek ve sağlıklı bir okul kültürünün oluşması için emek ve fedakarlıklarda bulunmak okul müdürlerinin görevidir (Bursalığlu, 1982). Yönetimsel başarıda etkili olabileceği düşünülen örgütsel bağlılık, örgüt ile müdür arasındaki psikolojik sözleşmenin bir sonucudur. Bu ilişkide müdürler, sahip oldukları yeteneklerini örgütte sergiler ve bilgilerini kullanırlar (Hicks, 1977). Yönetsel güçlülüğe sahip okul müdürlerinin bulunduğu okullarda sorunlarla daha az karşılaşıldığı, karşılaşılsa bile daha hızlı ve etkili çözümler bulunduğu düşünülmektedir. Çünkü yönetsel güçlülüğe sahip okul müdürleri; yönetsel bilgi, beceri ve yetenekleri elinde bulunduran; bu üçünü etkili olarak kullanabilen kişilerdir (Kanungo ve 
Menon, 2005). Herzberg'in (1959) çift etken motivasyon kuramına göre, örgütteki müdürün çalıştığ ortamdaki hijyen ve motive faktörlerden etkilenmesi beklenmektedir. Hijyen faktörler daha çok bireyin dışında gelişen ve işin özellikleri ile ilgili olan faktörlerdir. Bunlar, çalışma koşulları, yöneticilerle ilişkiler, ücret, statü, işgüvenliği, örgüt politikası ve uygulanması, çalışanlar arası ilişkiler, personel yaşamı gibi faktörlerdir. Motivasyon faktörler ise daha çok bireyin içinden gelen ve psikolojik olguları içeren; başarı, tanınma, sorumluluk, işin kendisi, ilerleme ve gelişme imkanlarıdır. Zeynel ve Çarıkçı (2015) mesleki motivasyon düzeyinin iş tatmin düzeyini ve örgütsel bağlılık düzeyini güçlü ve pozitif yönde etkilediğini bulmuşlardır. Bu anlamda müdürlerin, okula bağlılıkları ile yönetsel güçlülükleri arasında önemli bir bağın var olduğu düşünülebilir. Örgütsel bağlılıkla ilgili çalışmalar incelendiğinde Grusky (1966) ile başlayan birçok farklı sınıflandırmayla (Allen Mayer, 1984; Etzioni, 1961; O’Reilly ve Chatman, 1986; Staw ve Salancik, 1977; van Breukelen, 1996; Wiener, 1982 vb) karşılaşılmaktadır. Etzioni (1961) örgütsel bağlılığı ahlaki, hesaplı ve yabanlaştırıcı bağlılık olarak; Wiener (1982) araçsal ve örgütsel bağlılık olarak; Staw ve Salancik (1977) ise davranışsal, tutumsal ve duygu temelli örgütsel bağlılık olarak sınıflandırmıştır. Literatürde birçok örgütsel bağlılık araştırmasına kaynak olan Allen ve Meyer 1984 yılındaki çalışmasında örgütsel bağlılığı devam, duygusal ve normatif bağlılık olarak incelemiştir. Çalışmada Balay (2000)'ın örgütsel bağlılık ölçeği kullanılmıştır. Balay’ın (2000) örgütsel bağlılık boyutları, Q'Reilly ve Chatman'in (1986) çalışmasında olduğu gibi; uyum, özdeşleşme ve içselleştirme bağlılığı olarak 3 boyutta incelenmiştir. Uyum, ödüle dayalı bir araçsal bağlanmayı; özdeşleşme, örgütsel yaşamda çalışanların tutum ve davranışları ile örgütsel değer ve inançlar uyumlu ise olumlu davranışların sergilenmesi devam etmesi sonucu oluşan bağlılığı ve içselleştirme ise çalışanların ve örgütlerin değerleri arasında bir uygunluk söz konusu ise bunun sonucunda oluşan bağlılı̆̆ ifade etmektedir.

Yönetsel güçlülüğe sahip bireyler, sadece yönetim alanında yeterli bilgiye sahip olan, yönetimsel becerileri bulunduran ya da yönetimsel yetenekleri bulunan kişiler değillerdir. Yönetsel güçlülük; yönetimsel bilgilerin, becerilerin ve yeteneklerin toplamı ve bunlar arasındaki sinerjidir (Kanungo ve Menon, 2005). Bir başka deyişle; yönetsel güçlülüğe sahip bireyler gerekli yönetsel bilgiye sahip, uygun yönetsel beceri ve yetenekleri elinde bulunduran ve bu bilgi, beceri ve yetenekleri arasında uyum sağlayabilen kişiler olduğu düşünülebilir. Bu kişilerin duyuşsal, bilişsel ve davranışsal anlamda donanımlı olmaları beklenebilir.

Bireylerin kişilikleri olduğu gibi okulların da kendilerine özel iklimleri vardır. Çalışanların davranışlarını etkileyen, okuldaki psikolojik ortamı yansıtan ve okulları birbirinden ayıran iç özellikler bütünü, okul iklimidir. Okul müdürleri okul ikliminin oluşturulmasında başlıca görevli kişilerdir. Yönetimsel anlamda güçlü okul müdürleri etkili bir okul iklimi yaratarak çalışanların iş doyumlarını ve motivasyonlarını arttırabilir ve sağlıklı bir okul ikliminin oluşmasını sağlayabilir (Çelik, 2000). Bir başka deyişle okul müdürlerinin yönetsel güçlülüğü okulun iklimini belirlemekte; bu iklim de okuldaki öğretmenlere, öğrencilere ve velilere yansımaktadır. Okul müdürlerinin planlama, karar verme, denetleme, iletişim kurma ve etkileme (liderlik) becerileri yönetimsel anlamda etkili ve güçlü olmalarını sağlamaktadır (Cook, 2008). Okul müdürlerinin davranışları, insanlar arası iletişimi, yönetim ilkeleri, 
inançları, tutum ve tavırları okul ikliminin şekillenmesinde en temel faktörlerden biri olup onların bu davranışlarında sahip oldukları örgütsel bağlılıkları önemli bir itici güç olmaktadır. Bu nedenle okul müdürlerinin yönetsel bilgi ve becerileri(güçlülüğ̈̈) ile örgütsel bağlılıklarının ilişkisi önemli bir çalışma konusu olarak karşımıza çıkmaktadır.

Alanyazın incelendiğinde örgütsel bağlılık ile yönetsel güçlülük arasındaki ilişkiye yönelik çalışma ile karşılaşılmamıştır. Alanyazına bu anlamda katkı sağlayacağı düşünülen bu çalışmanın amacı, okul müdürlerinin yönetsel güçlülük düzeylerini belirlemek; yönetsel güçlülüklerinin hangi değişkenlere bağl1 olduğunu tespit etmek ve okul müdürlerinin yönetsel güçlülükleri ile örgütsel bağlılıkları arasındaki ilişkiyi ortaya koymaktır. Bu doğrultuda uygulanacak olan ölçekler okul müdürlerinin yönetsel güçlülükleri ve örgütsel bağlılıkları ile ilgilidir. Fakat, okul müdürlerinin olanı değil, olması gerekeni cevap verme ihtimalleri göz önünde bulundurularak çalışma, daha yansız sonuç vermesi ve müdürlerle aynı çalışma ortamlarında ve okul kültüründe bulunmaları açısından öğretmenlerle gerçekleştirilmiştir. Araştırmada ele alınan alt problemler aşağıda verilmektedir:

1) Okul müdürlerinin yönetsel güçlülük düzeyleri nedir?

2) Okul müdürlerinin bilişsel, duyuşsal ve davranışsal boyutlarındaki yönetsel güçlülükleri ne düzeydedir?

3) Öğretmenlerin; okul müdürlerinin bilişsel, duyuşsal ve davranışsal boyutlardaki yönetsel güçlülüklerine ve toplam yönetsel güçlülüklerine ilişkin algıları, onların (a)cinsiyetlerine, (b)branşlarına, (c)kıdemlerine, (d)öğretmen sayısına, (e)öğrenci sayısına, (f)müdürün görev yılına, (g)müdür yardımcısı sayısına göre anlamlı bir farklılık göstermekte midir?

4) Okul müdürlerinin yönetsel güçlülükleri ile örgütsel bağlılıkları arasında anlamlı bir ilişki var midir?

5) Okul müdürlerinin yönetsel güçlülük boyutları ile örgütsel bağlılık boyutları arasında anlamlı bir ilişki var mıdır?

6) Okul müdürlerinin örgütsel bağlılıkları, onların yönetsel güçlülüklerinin anlamlı bir yordayıcısı midir?

7) Okul müdürlerinin örgütsel bağlılık boyutları, yönetsel güçlülük boyutlarının anlamlı yordayıcıları midır?

\section{Yöntem}

\section{Araştırmanın Modeli}

Araştırma ilişkisel tarama modelinde ele alınmıştır. Karasar’a (1998) göre değişkenler arasındaki değişimin varlığını ve derecesini belirlemeyi amaçlayan araştırma modeli ilişkisel tarama modelidir. Bu çalışmada okul müdürlerinin yönetsel güçlülükleri ile örgütsel bağlılıkları arasındaki ilişkinin varlığı ve derecesi belirlenmeye çalışıldığı için ilişkisel tarama modeli kullanılmıştır. Verilerin girilmesinde ve 
çözümlenmesinde SPSS'den yararlanılmıştır. Araştırmada değişkenlerin birlikte değişip değişmedikleri, birlikte bir değişim varsa bunun ne şekilde olduğu belirlenmeye çalışılmıştır.

\section{Evren ve Örneklem}

2016-2017 eğitim-öğretim yılında Denizli’nin merkez ilçelerindeki (Pamukkale (1271) ve Merkezefendi (1448)) devlet ortaokullarında çalışan 2719 öğretmen, çalışmanın evrenini oluşturmaktadır. Çalışmanın örneklemi seçilirken basit seçkisiz örnekleme yöntemi kullanılmış ve Gay ve Airasan (1996) doğrultusunda örneklem sayısı en az 338 öğretmen olarak belirlenmiştir. Bu doğrultuda çalışma, 26 farklı ortaokuldaki 341 ortaokul öğretmeni ile gerçekleştirilmiş ve yeterli örnekleme ulaşılmıştır. Araştırmaya katılan öğretmenlerin demografik özellikleri Tablo 2'de verilmiştir.

Tablo 2. Araştırmaya katılan öğretmenlerin demografik özellikleri

\begin{tabular}{cccc}
\hline Kişisel Bilgiler & & Frekans $(n)$ & Yüzde (\%) \\
\hline Cinsiyet & Kadın & 191 & 56 \\
& Erkek & 150 & 44 \\
& Sayısal & 97 & 28,4 \\
Branş & Sözel & 121 & 35,5 \\
& Sanat-Spor & 48 & 14,1 \\
& Yabancı dil & 75 & 22,0 \\
Kıdem & & & 25,5 \\
& $0-10$ y1l arası & 87 & 54,3 \\
& $11-20$ yıl arası & 185 & 20,2 \\
Öğretmen Sayısı & 21 ve üzeri & 69 & 23,8 \\
& & & 19,9 \\
& $0-20$ arası & 81 & 21,1 \\
& $21-40$ arası & 68 & 35,2 \\
Öğrenci Sayısı & $41-60$ arası & 72 & 32,3 \\
& 61 ve üzeri & 120 & 21,7 \\
& & & 46,0
\end{tabular}

\section{Veri Toplama Araçları}

Araştırmada, veri toplama aracı olarak Şahin’in (2009) “Yönetsel Güçlülük Ölçeği” ve Balay’ın (2000) “Örgütsel Bağlılık Ölçeği” kullanılmıştır. Yönetsel Güçlülük Ölçeği üç boyuttan oluşmaktadır. Bunlar, bilişsel, duyuşsal ve davranışsal güçlülüktür. Ölçekteki maddelerin bu üç boyuta dağılımı Tablo 3'te verilmiştir. 
Tablo 3. Yönetsel güçlülük ölçeği'ndeki boyutlara ilişkin maddeler

\begin{tabular}{ll}
\hline Boyutlar & Maddeler \\
\hline Duyuşsal Güçlülük & $1,2,5,7,10,13,16,22,25,26,30,31,37,38,45,48$ \\
Bilişsel Güçlülük & $4,6,8,11,14,15,18,21,23,27,29,32,36,40,41,46,49$ \\
Davranışsal Güçlülük & $3,9,12,17,19,20,24,28,33,34,35,39,42,43,44,47,50,51$ \\
\hline
\end{tabular}

Şahin'in (2009) Yönetsel Güçlülük Ölçeği 50 maddeden oluşmaktadır. Çalışmada kullanılacak olan bu ölçeğin kapsam geçerliliği için eğitim alanında çalışan yedi uzmanın görüş ve önerilerine başvurulmuştur. Uzman görüşleri doğrultusunda “Öğretmenlerinin istek, ihtiyaç ve yeteneklerinin farkındadır" maddesi; 2 farklı maddeye ayrılmış ve öğretmenlere "Öğretmenlerin istek ve ihtiyaçlarına dikkat eder” ve "Öğretmenlerin yeteneklerinin farkındadır” olarak sorulmuştur. Böylece ölçek 51 madde haline gelmiştir. 51 maddelik ölçek yine üç boyuttan oluşmuştur ve ikiye ayrılan 34. ve 35. maddeler yine davranışsal güçlülük boyutunda yer almıştır. Uygun şekilde doldurulmadığı belirlenen 38 veri grubu değerlendirmeye alınmamıştır. Yönetsel Güçlülük Ölçeği'nin boyutlar bazında madde analizleri yapılmış ve Cronbach Alpha iç tutarlık katsayıları; "YG $\mathrm{Y}_{\text {Duyuşsal }}=.877, \mathrm{YG}_{\text {Bilişsel }}=.940, \mathrm{YG}_{\text {Davranışsal }}=.932$ ve ölçeğin toplam güvenirliği $\mathrm{YG}_{\text {toplam }}=.972$ olarak hesaplanmıştır.

Balay’ın (2000) geliştirdiği “Örgütsel Bağlılık Ölçeği” üç boyutlu (içselleştirme, özdeşleşme ve uyum) 5’li likert bir ölçektir (bkz. Tablo 4). Balay’ın (2000) “Örgütsel Bağlılık Ölçeği’ndeki maddeler çalışmanın amacı doğrultusunda öğretmenlerin okul müdürünün örgütsel bağlılığına ilişkin algılarını belirlemeye yönelik uyarlanmıştır. Örneğin orijinal ölçekte yer alan “ Bu okula uyum sağlamada güçlük çekiyorum.” maddesi öğretmenlerin müdürlerine yönelik yanıtlayacağı şekilde "Okul müdürü, okula uyum sağlamakta güçlük çekmektedir.” maddesine dönüştürülmüştür. Ayrıca uzman görüşleri doğrultusunda 5’li likert olan ölçek “orta düzey katılıyorum” bölmesi çıkartılarak 4'lü likert tipinde uygulanmıştır. Şahin'in (2009) Yönetsel Güçlülük Ölçeği ve Balay’ın (2000) Örgütsel Bağlılık Ölçeği gerekli düzenlemeler yapılıp son haline getirildikten sonra 118 kişilik bir grupla pilot çalışma yapılmıştır. Ölçeğin yapı geçerliliği için açımlayıcı ve doğrulayıcı faktör analizleri yapılmıştır. Yönetsel güçlülük ölçeğinde yine üç boyut, Örgütsel bağl1lık ölçeğinde yine üç boyut bulunmuştur.

Tablo 4. Örgütsel bağl1lık ölçeği’ndeki boyutlara ilişkin maddeler

\begin{tabular}{ll}
\hline Boyutlar & Maddeler \\
\hline Uyum & $1,2,3,4,5,6,7,8$ \\
Özdeşleşme & $9,10,11,12,13,14,15,16$ \\
İçselleştirme & $17,18,19,20,21,22,23,24,25,26,27$ \\
\hline
\end{tabular}

Ölçeğin kapsam geçerliliği için eğitim alanında çalışan on uzmana gönderilmiş, bunlardan yedi tanesinden dönüt alınmıştır. Bu yedi uzmanın görüşleri doğrultusunda ölçek düzenlenmiş ve pilot çalışma yapılmıştır. Ölçeğin yapı geçerliği için faktör analizleri (açımlayıcı ve doğrulayıcı) yapılmıştır. Uyarlanan ölçek yine 27 madde ve 3 boyuttan (uyum, özdeşleşme ve içselleştirme) oluşmaktadır. Örgütsel Bağl1lık Ölçeği'nin boyutlara göre madde analizi grçekleştirilmiş ve Cronbach Alpha iç tutarlık katsayıları;

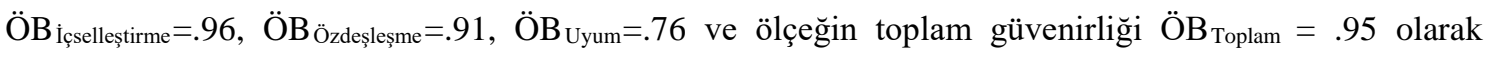
hesaplanmıştır. 


\section{Verilerin Analizi}

Okul müdürünün yönetsel güçlülüğüne ve boyutlara ilişkin öğretmen algılarını (1. ve 2 . alt problemler) belirlerken ve yorumlarken betimsel istatistikten yararlanılmıştır. 3. alt problemde öğretmenlerin, okul müdürünün yönetsel güçlülüğüne ilişkin algılarının, onların bazı özelliklerine göre anlamlı düzeyde farklılaşıp farklılaşmadığını belirlemek ve kullanılacak testleri saptamak amacıyla puanların normal dağılıma uygunluğu (Kolmogrov Smirnov) test edilmiştir. $Y_{\text {Duyussal }}$ (KSz=1.153; $p>$ $.05)$ ile $\mathrm{YG}_{\text {Bilisssel }}(\mathrm{KSz}=1.465 ; p>.05)$ normal dağılım gösterdiği, $\mathrm{YG}_{\text {Davranıssal }}(\mathrm{KSz}=1.76 ; p<.05)$ ise göstermediğine ulaşılmıştır. ÖB $\mathrm{B}_{\mathrm{Uyum}}(\mathrm{KSz}=3.876 ; p<.05)$, ÖB Özdeslleṣme $(\mathrm{KSz}=1.511 ; p<.05)$, ÖB $\mathrm{B}_{\text {Ịsselleştirme }}(\mathrm{KSz}=1.950 ; p<.05), \mathrm{ÖB}_{\text {Toplam }}(\mathrm{KSz}=1.462 ; p<.05)$ normal dağıllım göstermediğ sonucunu vermiştir. Normal dağılım göstermeyen veriler nonparametrik; normal dağılım gösterenler parametrik vardamsal istatistik teknikleriyle analiz edilmiş̧ir. Müdürlerin yönetsel güçlülük ve örgütsel bağl1lıkları arasındaki ilişkiyi (4. alt problem) ve müdürlerin yönetsel güçlülük boyutları ile örgütsel bağlılık boyutları arasındaki ilişkiyi (5. alt problem) saptamak amacıyla Pearson Korelasyon analizi uygulanmıştır. Değerler yorumlanırken; $.00<r<.25$ çok zayıf ilişki, . $26<r<.49$ zayıf ilişki, $.50<r<$ .69 orta ilişki, $.70<r<.89$ yüksek ilişki, $.90<r<1.00$ çok yüksek ilişki (Kalaycı, 2016) olduğu kabul edilmiştir. Müdürlerin örgütsel bağll1ıklarının, onların yönetsel güçlülüklerini nasıl yordadığını (6.alt problemi) bulmak için basit doğrusal regresyon kullanılmıştır. Müdürlerin örgütsel bağlllık boyutlarının, yönetsel güçlülük boyutları üzerindeki yordama gücünü belirlemek için (7. alt problemi) çoklu regresyon kullanılmıştır.

\section{Bulgular}

'Yönetsel Güçlülük Ölçeği’ ve ‘Örgütsel Bağlllık Ölçeği’nden elde edilen veriler, alt problemlere yanıt verecek uygun nicel veri analizi teknikleriyle analiz edilmiştir. Bulgular tablolarla birlikte aşağıda verilmektedir.

\section{Müdürün Yönetsel Güçlülük Düzeyleri}

Araştırmanın 1. alt problemi “Okul müdürlerinin yönetsel güçlülükleri ne düzeydedir?” biçiminde belirlenmiştir (bkz. Tablo 5). Bu alt probleme yanıt vermek amacıyla betimsel istatistik teknikleri uygulanmıştır.

Tablo 5. Müdürünün yönetsel güçlülük ve boyutlarının düzeyleri

\begin{tabular}{ccll}
\hline Boyutlar & $n$ & $\bar{x}$ & Ss \\
\hline Duyuşsal Güçlülük & 341 & 3.59 & .62 \\
Bilişsel Güçlülük & 341 & 3.84 & .72 \\
Davranışsal Güçlülük & 341 & 3.79 & .70 \\
Yönetsel Güçlülük (Toplam) & 341 & 3.74 & .66 \\
\hline
\end{tabular}

Öğretmenlerin, müdürün yönetsel güçlülüğüne ilişkin algıları 5'li likert tipi ölçekle ölçülmüştür. Okul müdürlerine yönelik öğretmen algılarının aritmetik ortalamaları incelenmiştir. Ortalamalar, 4.21-5.00 arasında çok yüksek; 3.41-4.20 arasında yüksek; 2.61-3.40 arasında orta; 1.81-2.60 arasında düşük; 1.00- 
1.80 arasında çok düşük yönetsel güçlülüğe sahip şeklinde belirlenmiştir. Tablo 5’te, müdürün yönetsel güçlülük düzeylerine ilişkin öğretmen algılarının duyuşsal, bilişsel, davranışsal boyutlarda ve toplam yönetsel güçlülükte yüksek düzeyde olduğu bulunmuştur (YG Bilişsel $_{1}=3.84 ;$; YG $G_{\text {Davranışsal }}=3.59$; $Y_{\text {Duyuşsal }}=3.59$; $Y G_{\text {toplam }}=3.74$ ). Öğretmenler müdürlerinin sırasıyla bilişsel, davranışsal ve duyuşsal güçlülüğe yüksek düzeyde sahip olduklarını düşünmektedirler. Öğretmen algılarına göre müdürlerin en yüksek düzeyde sahip olduğu yönetsel güçlülük davranışları Tablo 6’da verilmiştir.

Tablo 6. Müdürlerde en yüksek düzeyde sahip olunan yönetsel güçlülük davranışlarına ilişkin bazı veriler ve yönetsel güçlülük düzeyleri

\begin{tabular}{lccc}
\hline \multicolumn{1}{c}{ Maddeler } & $n$ & $\bar{x}$ & Ss \\
\hline 33) Plansız çalışır.* & 341 & 1.57 & .773 \\
24) İyi bir dinleyici değildir.* & 341 & 1.73 & .996 \\
$\begin{array}{l}\text { 46)Bir problemle karşılaştığında, o durumla } \\
\text { başedebileceğinden genellikle pek emin }\end{array}$ & 341 & 1.88 & .950 \\
değildir*. & & & \\
\end{tabular}

Tablo 6’ya göre öğretmenler, okul müdürlerinin planlı olarak çalıştıklarını, iyi bir dinleyici rolü üstlendiklerini (çok yüksek düzeyde) ve bir problemle karşılaştıklarında o problemle baş edebileceklerini (yüksek düzeyde) düşünmektedirler. Öğretmen algılarına göre müdürlerin en düşük düzeyde sahip olduğu yönetsel güçlülük davranışları Tablo 7’de verilmiştir.

Tablo 7. Müdürlerde en düşük düzeyde sahip olunan yönetsel güçlülük davranışlarına ilişkin bazı veriler ve yönetsel güçlülük düzeyleri

\begin{tabular}{lccc}
\hline \multicolumn{1}{c}{ Maddeler } & $n$ & $\bar{x}$ & Ss \\
\hline 25) Başarısız olmaktan korkar. & 341 & 2.23 & 1.218 \\
\hline 12)Öğretmenler için zor ve belirgin hedefler belirler. & 341 & 2.71 & 1.079 \\
\hline $\begin{array}{l}\text { 51)Onun için zamandan çok işlerin bitirilmesi } \\
\text { önemlidir.* }\end{array}$ & 341 & 2.91 & 1.147 \\
\hline
\end{tabular}

Tablo 7'ye göre öğretmenler, müdürlerin başarısız olmaktan çok fazla korkmadıklarını, öğretmenler için zaman zaman zor ve belirgin hedefler belirlediklerini ve işlerin bitirilmesiyle kıyaslandığında zaman konusunda daha az hassas olduklarını düşünmektedir.

\section{Müdürünün Yönetsel Güçlülük ve Boyutlarının Düzeylerinin Öğretmenlerin Bazı Özelliklerine}

\section{Göre İncelenmesi}

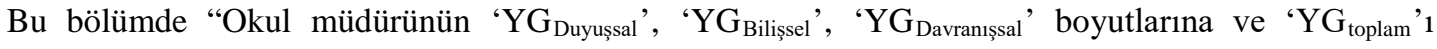
öğretmenlerin cinsiyetlerine, branşlarına, müdürün okuldaki görev yılına, okullarındaki müdür yardımcısı, öğrenci ve öğretmen sayısına göre anlamlı olarak farklılaşmakta mıdır?” alt problemi dikkate alınmış ve ilgili bulgulara yer verilmiştir. Veriler incelendiğinde, 'YG $\mathrm{G}_{\text {Duyuşsal' ve 'YG }}$ Bilişsel ' boyutları ve $\mathrm{YG}_{\text {toplam }}$

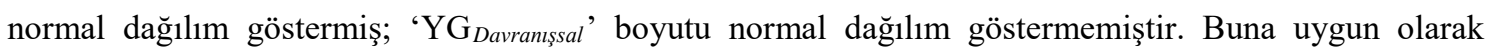
parametrik ve nonparametrik testler uygulanmıştır. 
a) Cinsiyet: Öğretmen algılarına göre, müdürün yönetsel güçlülüğü cinsiyete göre incelenirken 'YG $G_{\text {Duyuşsal }}$ ' ve 'YG Bilişsel' boyutları ve $Y_{\text {toplam }}$ için Independent Sample t testinden, 'YG $G_{\text {Davranışsal }}$ ' boyutu için Mann Whitney U testinden yararlanılmıştır (bkz. Tablo 8).

Tablo 8. Müdürünün yönetsel güçlülük ve boyutlarının cinsiyet değişkenine göre analizi

\begin{tabular}{|c|c|c|c|c|c|c|c|}
\hline & Değişken & Kategori & $n$ & $\bar{x}$ & Ss & $t$ & $p$ \\
\hline \multirow{2}{*}{$Y G_{\text {Duyussal }}$} & \multirow{2}{*}{ Cinsiyet } & Kadın & 191 & 3.56 & .66 & \multirow{2}{*}{-1.114} & \multirow{2}{*}{.174} \\
\hline & & Erkek & 150 & 3.63 & .57 & & \\
\hline \multirow{2}{*}{$Y G_{\text {Bilişsel }}$} & \multirow{2}{*}{ Cinsiyet } & Kadın & 191 & 3.82 & .75 & \multirow{2}{*}{-.584} & \multirow{2}{*}{.070} \\
\hline & & Erkek & 150 & 3.87 & .68 & & \\
\hline \multirow{3}{*}{$Y G_{\text {toplam }}$} & \multirow{2}{*}{ Cinsiyet } & Kadın & 191 & 3.72 & .45 & \multirow{2}{*}{-.689} & \multirow{2}{*}{.085} \\
\hline & & Erkek & 150 & 3.77 & .44 & & \\
\hline & Değişken & $\begin{array}{c}\text { Kategor } \\
i \\
\end{array}$ & $n$ & $\begin{array}{c}\text { Sira } \\
\text { Toplamı } \\
\end{array}$ & $\begin{array}{c}\text { Sira } \\
\text { Ortalamast } \\
\end{array}$ & $U$ & $Z$ \\
\hline \multirow[t]{2}{*}{$Y G_{\text {Davranıssal }}$} & \multirow{2}{*}{ Cinsiyet } & Kadın & 191 & 32221.5 & 168.70 & \multirow{2}{*}{13885.5} & \multirow{2}{*}{-.487} \\
\hline & & Erkek & 150 & 26089.5 & 173.93 & & \\
\hline
\end{tabular}

Müdürünün yönetsel güçlülüğüne (boyutlar ve toplamda) ilişkin algılarında öğretmenlerin cinsiyetlerine göre .05 düzeyinde anlamlı bir fark bulunmamıştır (p>.05). Bir başka deyişle; duyuşsal, bilişsel, davranışsal boyutlarda ve toplamda erkek ve kadın öğretmenlerin müdürün yönetsel güçlülüklerine yönelik algılarının benzer olduğu görülmüştür.

b) Kıdem: Öğretmen algılarına göre müdürün yönetsel güçlülüğü kıdeme göre incelenirken 'YG $\mathrm{G}_{\text {Duyusssal', 'YG }} \mathrm{G}_{\text {Bilisssel }}$ 've 'YG $\mathrm{G}_{\text {toplam }}$ ' boyutları için One Way Anova testinden; 'YG $\mathrm{G}_{\text {Davranıssal }}$ ' boyutu için Kruskall Wallis testinden yararlanılmıştır (bkz. Tablo 9). 
Tablo 9. Müdürünün yönetsel güçlülük ve boyutların kıdem değişkenine göre analizi

\begin{tabular}{|c|c|c|c|c|c|c|c|}
\hline & Değişken & Kategori & $n$ & $\overline{\bar{x}}$ & Ss & $F$ & $p$ \\
\hline \multirow{3}{*}{$Y G_{\text {Duyusssal }}$} & \multirow{3}{*}{ Kidem } & $0-10 \mathrm{y} 1 \mathrm{l}$ & 87 & 3.59 & .820 & \multirow{3}{*}{.235} & \multirow{3}{*}{.791} \\
\hline & & $11-20$ y1l & 185 & 3.54 & .889 & & \\
\hline & & $\begin{array}{c}21 \text { yll ve } \\
\text { üzeri }\end{array}$ & 69 & 3.61 & .101 & & \\
\hline \multirow{3}{*}{$Y G_{\text {Bilişsel }}$} & \multirow{3}{*}{ Kidem } & $0-10 \mathrm{y} 1 \mathrm{l}$ & 87 & 3.89 & .762 & \multirow{3}{*}{1.008} & \multirow{3}{*}{.366} \\
\hline & & $11-20$ y1l & 185 & 3.86 & .742 & & \\
\hline & & $\begin{array}{c}21 \text { yll ve } \\
\text { üzeri }\end{array}$ & 69 & 3.73 & .609 & & \\
\hline \multirow{3}{*}{$Y G_{\text {toplam }}$} & \multirow{3}{*}{ Kidem } & $0-10 \mathrm{y} 1 \mathrm{l}$ & 87 & 3.77 & .713 & \multirow{3}{*}{.799} & \multirow{3}{*}{.451} \\
\hline & & $11-20$ y1l & 185 & 3.76 & .686 & & \\
\hline & & $\begin{array}{c}21 \text { yll ve } \\
\text { üzeri }\end{array}$ & 69 & 3.65 & .557 & & \\
\hline & Değişken & Kategori & $n$ & Sira & amast & $\chi$ & $p$ \\
\hline \multirow{3}{*}{$Y G_{\text {Davranıssal }}$} & \multirow{3}{*}{ Kidem } & $0-10$ y1l & 87 & & & \multirow{3}{*}{2.907} & \multirow{3}{*}{.234} \\
\hline & & $11-20$ y1l & 185 & & & & \\
\hline & & $\begin{array}{l}21 \text { yll ve } \\
\text { üzeri }\end{array}$ & 69 & & & & \\
\hline
\end{tabular}

Müdürün yönetsel güçlülüğünde (boyutlar ve toplamda) öğretmenlerin kıdemlerine göre .05 düzeyinde anlamlı fark bulunmamıştır $(p>.05)$. Duyuşsal, bilişsel, davranışsal boyutlar ve toplamda öğretmenlerin müdürün yönetsel güçlülüğüne yönelik algılarının kıdeme göre benzer olduğu görülmüştür.

c) Branş: Öğretmen algılarına göre müdürün yönetsel güçlülüğü branşa göre incelenirken 'YG $\mathrm{G}_{\text {Duyussal }}$ ', 'YG $\mathrm{B}_{\text {Bilissel }}$ ' ve 'YG $\mathrm{G}_{\text {toplam }}$ ' boyutları için One Way Anova testinden ; 'YG $\mathrm{G}_{\text {Davranıssal }}$ ' boyutu için Kruskall Wallis testinden yararlanılmıştır (bkz. Tablo 10). 
Tablo 10. Müdürünün yönetsel güçlülük ve boyutların branş değişkenine göre analizi

\begin{tabular}{|c|c|c|c|c|c|c|c|}
\hline & Değişken & Kategori & $n$ & $\overline{\bar{x}}$ & Ss & $F$ & $p$ \\
\hline \multirow{4}{*}{$\mathrm{YG}_{\text {Duyusssal }}$} & \multirow{4}{*}{ Branş } & Sayisal & 97 & 3.57 & .583 & \multirow{4}{*}{.930} & \multirow{4}{*}{.426} \\
\hline & & Sözel & 121 & 3.64 & .620 & & \\
\hline & & Yabanc1 Dil & 48 & 3.47 & .691 & & \\
\hline & & Sanat-Spor & 75 & 3.61 & .660 & & \\
\hline \multirow{4}{*}{$\mathrm{YG}_{\text {Bilişsel }}$} & \multirow{4}{*}{ Branş } & Sayısal & 97 & 3.78 & .683 & \multirow{4}{*}{.959} & \multirow{4}{*}{.412} \\
\hline & & Sözel & 121 & 3.92 & .711 & & \\
\hline & & Yabancı Dil & 48 & 3.75 & .839 & & \\
\hline & & Sanat-Spor & 75 & 3.84 & .719 & & \\
\hline \multirow{5}{*}{$\mathrm{YG}_{\text {toplam }}$} & \multirow{4}{*}{ Branş } & Sayısal & 97 & 3.69 & .650 & \multirow{4}{*}{1.132} & \multirow{4}{*}{.336} \\
\hline & & Sözel & 121 & 3.82 & .657 & & \\
\hline & & Yabanc1 Dil & 48 & 3.64 & .742 & & \\
\hline & & Sanat-Spor & 75 & 3.74 & .663 & & \\
\hline & Değişken & Kategori & $n$ & & Drtalamast & $\chi$ & $p$ \\
\hline \multirow{4}{*}{$\mathrm{YG}_{\text {Davranlsssal }}$} & \multirow{4}{*}{ Branş } & Sayısal & 97 & & 61.66 & \multirow{4}{*}{4.162} & \multirow{4}{*}{.245} \\
\hline & & Sözel & 121 & & 85.05 & & \\
\hline & & Yabancı Dil & 48 & & 58.41 & & \\
\hline & & Sanat-Spor & 75 & & 68.47 & & \\
\hline
\end{tabular}

Müdürün yönetsel güçlülüğünde (boyutlar ve toplamda) öğretmenlerin branşlarına göre .05 düzeyinde anlamlı fark bulunmamıştır ( $p>.05$ ). Duyuşsal, bilişsel, davranışsal boyutlar ve toplamda öğretmenlerin, müdürünün yönetsel güçlülüğüne yönelik algılarının branşlara göre benzer olduğu görülmüştür.

d) Öğretmen Sayısı: Öğretmen algılarına göre müdürün yönetsel güçlülüğü okullarındaki öğretmen sayısına göre incelenirken ' $\mathrm{YG}_{\text {Duyussal }}$ ', 'YG $\mathrm{Y}_{\text {Bilissel }}$ ' ve 'YG $\mathrm{Y}_{\text {toplam }}$ ' boyutları için One Way Anova testinden ; 'YG Davranıssal' boyutu için Kruskall Wallis testinden yararlanılmıştır (bkz. Tablo 11). 
Tablo 11. Müdürün yönetsel güçlülük ve boyutların okullarındaki öğretmen sayısı değişkenine göre analizi

\begin{tabular}{|c|c|c|c|c|c|c|c|}
\hline & De ğişken & Kategori & $n$ & $\bar{x}$ & Ss & $F$ & $p$ \\
\hline \multirow{4}{*}{$Y G_{\text {Duyusssal }}$} & & $0-20$ aras1 & 81 & 3.49 & .774 & \multirow{4}{*}{4.453} & \multirow{4}{*}{.004} \\
\hline & Öğretmen & $21-40$ aras1 & 68 & 3.71 & .613 & & \\
\hline & Say1s1 & $41-60$ aras1 & 72 & 3.42 & .611 & & \\
\hline & & 61 ve üzeri & 120 & 3.69 & .509 & & \\
\hline \multirow{4}{*}{$\mathrm{YG}_{\text {Bilisssel }}$} & & $0-20$ aras1 & 81 & 3.89 & .855 & \multirow{4}{*}{6.154} & \multirow{4}{*}{.000} \\
\hline & Öğretmen & $21-40$ aras1 & 68 & 3.96 & .665 & & \\
\hline & Say1s1 & $41-60$ aras1 & 72 & 3.53 & .645 & & \\
\hline & & 61 ve üzeri & 120 & 3.93 & .653 & & \\
\hline \multirow{4}{*}{$\mathrm{YG}_{\text {toplam }}$} & & $0-20$ aras1 & 81 & 3.74 & .788 & \multirow{4}{*}{6.004} & \multirow{4}{*}{.001} \\
\hline & Öğretmen & $21-40$ aras1 & 68 & 3.87 & .640 & & \\
\hline & Sayıs1 & $41-60$ aras1 & 72 & 3.47 & .579 & & \\
\hline & & 61 ve üzeri & 120 & 3.84 & .605 & & \\
\hline & Değişken & Kategori & $n$ & Stra $O$ & amast & $\chi$ & $p$ \\
\hline \multirow{4}{*}{$\mathrm{YG}_{\text {Davranıssal }}$} & \multirow{4}{*}{$\begin{array}{c}\text { Öğretmen } \\
\text { Say1s1 }\end{array}$} & $0-20$ aras1 & 81 & & & \multirow{4}{*}{23.012} & \multirow{4}{*}{.000} \\
\hline & & $21-40$ aras 1 & 68 & & & & \\
\hline & & $41-60$ aras1 & 72 & & & & \\
\hline & & 61 ve üzeri & 120 & & & & \\
\hline
\end{tabular}

Yapılan One Way Anova analizi sonucunda öğretmen sayısı farklı olan okullarda çalışan öğretmenlerin müdürün yönetsel güçlülüğüne ilişkin algılarında .05 manidarlık düzeyinde anlamlı farklılıklar olduğu belirlenmiştir $(p>.05)$. Varyansların eşitliğini test etmek ve anlamlı farkın nedenini araştırmak için Levene testi yapılmıştır. $\mathrm{YG}_{\text {Duyuşsal }}(\mathrm{L}=6,688 ; p<.05)$, $\mathrm{YG}_{\text {Bilisssel }}(\mathrm{L}=6,954 ; p<.05)$ boyutunda ve $\mathrm{YG}_{\text {toplam }}$ 'da $(\mathrm{L}=6,807 ; p<.05)$ varyanslar eşit değildir. $\mathrm{YG}_{\text {Davranısssal }}$ boyutu için yapılan Kruskall Wallis testinin analizi sonucunda öğretmen sayısı farklı olan okullarda çalışan öğretmenlerin müdürün yönetsel güçlülüğüne ilişkin algılarında .05 manidarlık düzeyinde anlamlı farklılıklar olduğu belirlenmiştir (Chi-Square $\chi=23.012 ; p<.05$ ). İkili Mann Whitney U testi karşılaştırmaları ile anlamlı farkın hangi grup/lar yönünde olduğunu belirlenmiştir (bkz. Tablo 11). Buna göre, yönetsel güçlülük ve boyutları için okul müdürüne ilişkin algılarda anlamlı farklılık ortaya çıkmıştır $(p<.05)$. 'YG $\mathrm{Guyuşsal}_{\text {' ve }}$ 'YG toplam boyutlarında; 41-60 arası öğretmeni olan okullardaki öğretmenlerin, 21-40 arası ve 61 ve üzeri öğretmeni olan okullardaki öğretmenlere göre okul müdürünün yönetsel güçlülüğüne ilişkin algıları daha

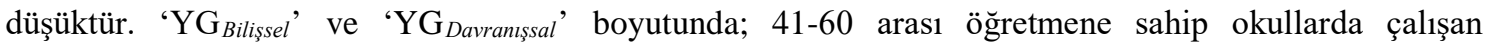
öğretmenlerin, diğer öğretmenlere göre müdürün yönetsel güçlülüğüne ilişkin algıları daha düşüktür. Okuldaki öğretmen sayısı 40’tan fazla olan okullardaki öğrenci mevcutları oldukça çoktur.

e) Öğrenci Sayısı: Öğretmen algılarına göre müdürün yönetsel güçlülüğü okullarındaki öğrenci

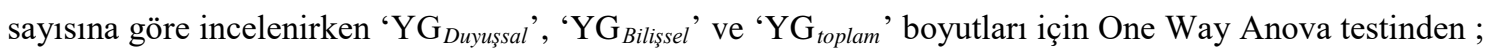

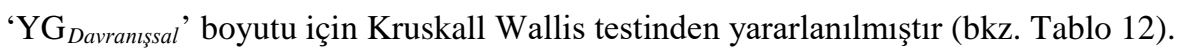


Tablo 12. Müdürün yönetsel güçlülük ve boyutların okullarındaki öğrenci sayısı değişkenine göre analizi

\begin{tabular}{|c|c|c|c|c|c|c|c|}
\hline & Değişken & Kategori & $n$ & $\bar{x}$ & Ss & $F$ & $p$ \\
\hline \multirow{3}{*}{$\mathrm{YG}_{\text {Duyussal }}$} & \multirow{3}{*}{$\begin{array}{c}\text { Öğrenci } \\
\text { Sayısı }\end{array}$} & 500’den az & 110 & 3.74 & .636 & \multirow{3}{*}{9.289} & \multirow{3}{*}{.000} \\
\hline & & $500-1000$ aras 1 & 74 & 3.34 & .678 & & \\
\hline & & 1000'den fazla & 157 & 3.60 & .565 & & \\
\hline \multirow{3}{*}{$\mathrm{YG}_{\text {Bilisssel }}$} & \multirow{3}{*}{$\begin{array}{c}\text { Öğrenci } \\
\text { Sayısı }\end{array}$} & 500’den az & 110 & 4.08 & .706 & \multirow{3}{*}{10.187} & \multirow{3}{*}{.000} \\
\hline & & $500-1000$ aras 1 & 74 & 3.62 & .731 & & \\
\hline & & 1000'den fazla & 157 & 3.78 & .689 & & \\
\hline \multirow{4}{*}{$\mathrm{YG}_{\text {toplam }}$} & \multirow{3}{*}{$\begin{array}{c}\text { Öğrenci } \\
\text { Sayıs1 }\end{array}$} & 500’den az & 110 & 3.95 & .646 & \multirow{3}{*}{10.524} & \multirow{3}{*}{.000} \\
\hline & & $500-1000$ aras 1 & 74 & 3.51 & .700 & & \\
\hline & & 1000'den fazla & 157 & 3.70 & .631 & & \\
\hline & Değişken & Kategori & $n$ & Stra $O$ & amasl & $\chi$ & $p$ \\
\hline \multirow{3}{*}{$\mathrm{YG}_{\text {Davranıssal }}$} & \multirow{3}{*}{$\begin{array}{c}\text { Öğrenci } \\
\text { Sayısı }\end{array}$} & 500’den az & 110 & & & \multirow{3}{*}{21.849} & \multirow{3}{*}{.000} \\
\hline & & $500-1000$ aras 1 & 74 & & & & \\
\hline & & 1000'den fazla & 157 & & & & \\
\hline
\end{tabular}

Yapılan One Way Anova analizi sonucunda öğrenci sayısı farklı olan okullardaki öğretmenlerin, müdürlerinin yönetsel güçlülüğüne ilişkin algılarında .05 manidarlık düzeyinde anlamlı farklılıklar olduğu belirlenmiştir $(p>.05)$. Varyansların eşitliğini test etmek ve anlamlı farkın nedenini araştırmak için Levene testi yapılmıştır. $\mathrm{YG}_{\text {Duyuşsal }}(\mathrm{L}=1.173 ; p>.05), \mathrm{YG}_{\text {Bilişsel }}(\mathrm{L}=0.255 ; p>.05)$ boyutunda ve $\mathrm{YG}_{\text {toplam }}$ 'da $(\mathrm{L}=.822 ; p>.05)$ varyanslar eşittir. $\mathrm{YG}_{\text {Davranıssal }}$ boyutu için yapılan Kruskall Wallis testinin analizi sonucunda öğrenci sayısı farklı okullardaki öğretmenlerin, müdürlerinin yönetsel güçlülüğüne ilişkin algılarında .05 manidarlık düzeyinde anlamlı farklılıklar olduğu belirlenmiştir (Chi-Square $\chi$ $=21.849 ; p<.05)$. İkili Mann Whitney U testi karşılaştırmaları ile anlamlı farkın hangi grup/lar yönünde olduğunu belirlenmiştir. Buna göre, yönetsel güçlülük ve boyutları için okul müdürüne ilişkin algılarda anlamlı farklılıklar ortaya çıkmıştır $(p<.05)$. ' $\mathrm{YG}_{\text {Duyusssal }}$ ' boyutunda 500-1000 arası öğrenciye sahip okullarda çalışan öğretmenlerin, diğer öğretmenlere göre müdürün yönetsel güçlülüğüne ilişkin algıları daha düşüktür, 'YG $\mathrm{G}_{\text {Bilissel', 'YG }} \mathrm{Yavranıssal}$ ' ve 'YG $\mathrm{G}_{\text {toplam }}$ ' boyutlarında ise 500'den az öğrenciye sahip okullarda çalışan öğretmenlerin, diğer öğretmenlere göre müdürün yönetsel güçlülüğüne ilişkin algıları daha yüksektir.

f) Müdür Yardımcısı Sayısl: Öğretmen algılarına göre okul müdürünün yönetsel güçlülüğü okuldaki müdür yardımcısı sayısına göre incelenirken ' $\mathrm{YG}_{\text {Duyuşsal', 'YG }} \mathrm{Bilisssel}_{\text {' ve 'YG }} \mathrm{G}_{\text {toplam }}$ ' boyutları için One Way Anova testinden; 'YG $\mathrm{G}_{\text {Davranısssal' }}$ boyutu için Kruskall Wallis testinden yararlanılmıştır (bkz. Tablo 13). 
Tablo 13. Müdürün yönetsel güçlülük ve boyutların okuldaki müdür yardımcısı sayısı değişkenine göre analizi

\begin{tabular}{|c|c|c|c|c|c|c|c|}
\hline & Değişken & Kategori & $n$ & $\bar{x}$ & Ss & $F$ & $p$ \\
\hline \multirow{3}{*}{$\mathrm{YG}_{\text {Duyusssal }}$} & Müdür & 1 & 86 & 3.70 & .648 & \multirow{3}{*}{7.109} & \multirow{3}{*}{.001} \\
\hline & Yardımcisı & 2 & 134 & 3.43 & .648 & & \\
\hline & Say1s1 & 3 ve üzeri & 121 & 3.69 & .559 & & \\
\hline \multirow{3}{*}{$\mathrm{YG}_{\text {Bilişsel }}$} & Müdür & 1 & 86 & 4.04 & .677 & \multirow{3}{*}{10.092} & \multirow{3}{*}{.000} \\
\hline & Yardımc1s1 & 2 & 134 & 3.64 & .761 & & \\
\hline & Sayıs1 & 3 ve üzeri & 121 & 3.93 & .656 & & \\
\hline \multirow{3}{*}{$\mathrm{YG}_{\text {toplam }}$} & Müdür & 1 & 86 & 3.92 & .631 & \multirow{3}{*}{10.267} & \multirow{3}{*}{.000} \\
\hline & Yardımcısı & 2 & 134 & 3.55 & .700 & & \\
\hline & Say1s1 & 3 ve üzeri & 121 & 3.83 & .608 & & \\
\hline & Değişken & Kategori & $n$ & \multicolumn{2}{|c|}{ Sira Ortalaması } & $\chi$ & $p$ \\
\hline \multirow{3}{*}{$\mathrm{YG}_{\text {Davranışsal }}$} & Müdür & 1 & 86 & \multicolumn{2}{|c|}{201.25} & & \\
\hline & Yardımcıs1 & 2 & 134 & \multicolumn{2}{|c|}{141.75} & 21.393 & .000 \\
\hline & Sayı1s1 & 3 ve üzeri & 121 & \multicolumn{2}{|c|}{181.90} & & \\
\hline
\end{tabular}

Yapılan One Way Anova analizi sonucunda öğretmen sayısı farklı olan okullarda çalışan öğretmenlerin müdürün yönetsel güçlülüğüne ilişkin algılarında .05 manidarlık düzeyinde anlamlı farklılıklar olduğu belirlenmiştir $(p>.05)$. Varyansların eşitliğini test etmek ve anlamlı farkın nedenini araştırmak için Levene testi yapılmıştır. $\mathrm{YG}_{\text {Duyusssal }}(\mathrm{L}=1.160 ; p>.05), \mathrm{YG}_{\text {Bilişsel }}(\mathrm{L}=2.307 ; p>.05)$ boyutunda ve $\mathrm{YG}_{\text {toplam }}$ 'da $(\mathrm{L}=2.023 ; p>.05)$ varyanslar eşittir. $\mathrm{YG}_{\text {Davranıssal }}$ boyutu için yapılan Kruskall Wallis testinin analizi sonucunda öğretmen sayısı farklı olan okullarda çalışan öğretmenlerin müdürün yönetsel güçlülüğüne ilişkin algılarında .05 manidarlık düzeyinde anlamlı farklılıklar olduğu belirlenmiştir (Chi-Square $\chi=21.393 ; p<.05$ ). İkili Mann Whitney U testi karşılaştırmaları ile anlamlı farkın hangi grup/lar yönünde olduğunu belirlenmiştir (bkz. Tablo 13). Buna göre, yönetsel güçlülük ve boyutları için okuldaki müdür yardımcısı sayısına göre müdürün yönetsel güçlülüğüne ilişkin algılarda anlamlı farklılıklar ortaya çıkmıştır $(p<.05)$. 'YG $\mathrm{G}_{\text {Duyuşsal' }}$ ', 'YG $\mathrm{G}_{\text {Bilişsel', 'YG }} \mathrm{G}_{\text {Davranışsal }}$ ve 'YG $\mathrm{G}_{\text {toplam }}$ ' boyutlarında; 2 müdür yardımcısına sahip okullarda çalışan öğretmenlerin, diğer öğretmenlere göre okul müdürünün yönetsel güçlülüğüne ilişkin algıları daha düşüktür.

g) Müdürün Okuldaki Görev Yıll: Öğretmen algılarına göre müdürün yönetsel güçlülüğü okuldaki

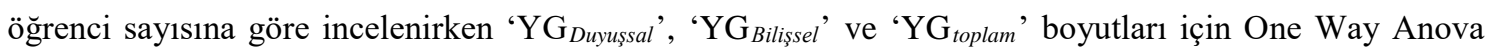
testinden ; 'YG Davranıssal' boyutu için Kruskall Wallis testinden yararlanılmıştır (bkz. Tablo 14). 
Tablo 14. Okul müdürünün yönetsel güçlülük ve boyutların müdürün görev yılına göre analizi

\begin{tabular}{|c|c|c|c|c|c|c|c|}
\hline & Değişken & Kategori & $n$ & $\overline{\bar{x}}$ & Ss & $F$ & $p$ \\
\hline \multirow{3}{*}{$\mathrm{YG}_{\text {Duyussal }}$} & Müdürün & 2 yildan az & 53 & 3.55 & .768 & \multirow{3}{*}{4.358} & \multirow{3}{*}{.014} \\
\hline & Görev & 2-4 yıl arası & 206 & 3.53 & .592 & & \\
\hline & Y1l1 & 4 yildan fazla & 82 & 3.77 & .594 & & \\
\hline \multirow{3}{*}{$\mathrm{YG}_{\text {Bilissel }}$} & Müdürün & 2 yildan az & 53 & 3.83 & .761 & \multirow{3}{*}{3.760} & \multirow{3}{*}{.024} \\
\hline & Görev & 2-4 yıl arası & 206 & 3.77 & .722 & & \\
\hline & Yil1 & 4 yıldan fazla & 82 & 4.03 & .674 & & \\
\hline \multirow{4}{*}{$\mathrm{YG}_{\text {toplam }}$} & Müdürün & 2 yıldan az & 53 & 3.74 & .722 & \multirow{3}{*}{3.921} & \multirow{3}{*}{.021} \\
\hline & Görev & 2-4 y1l arası & 206 & 3.67 & .658 & & \\
\hline & Y1l1 & 4 yıldan fazla & 82 & 3.92 & .637 & & \\
\hline & Değişken & Kategori & $n$ & Sira $C$ & amasl & $\chi$ & $p$ \\
\hline \multirow{3}{*}{$\mathrm{YG}_{\text {Davranısssal }}$} & Müdürün & 2 yildan az & 53 & \multicolumn{2}{|c|}{175.40} & \multirow{3}{*}{6.290} & \multirow{3}{*}{.043} \\
\hline & Görev & 2-4 y1l aras1 & 206 & \multirow{2}{*}{\multicolumn{2}{|c|}{$\begin{array}{l}161.09 \\
193.04\end{array}$}} & & \\
\hline & Y1l1 & 4 yıldan fazla & 82 & & & & \\
\hline
\end{tabular}

Yapılan One Way Anova analizi sonucunda öğretmen sayısı farklı olan okullarda çalışan öğretmenlerin, müdürün yönetsel güçlülüğüne ilişkin algılarında .05 manidarlık düzeyinde anlamlı farklılıklar olduğu belirlenmiştir $(p>.05)$. Varyansların eşitliğini test etmek ve anlamlı farkın nedenini araştırmak için Levene testi yapılmıştır. $\mathrm{YG}_{\text {Duyusssal }}(\mathrm{L}=2.954 ; p>.05), \mathrm{YG}_{\text {Bilişsel }}(\mathrm{L}=0.283 ; p>.05)$ boyutunda ve $\mathrm{YG}_{\text {toplam }}$ 'da $(\mathrm{L}=0.437 ; p>.05)$ varyanslar eşittir. $\mathrm{YG}_{\text {Davranıssal }}$ boyutu için yapılan Kruskall Wallis testinin analizi sonucunda öğretmen sayısı farklı olan okullarda çalışan öğretmenlerin müdürün yönetsel güçlülüğüne ilişkin algılarında .05 manidarlık düzeyinde anlamlı farklılıklar olduğu belirlenmiştir (Chi-Square $\chi=6.290 ; p<.05$ ). İkili Mann Whitney U testi karşılaştırmaları ile anlamlı farkın hangi grup/lar yönünde olduğunu belirlenmiştir. Buna göre, yönetsel güçlülük ve boyutları için müdürün okuldaki görev yılına göre yönetsel güçlülüğüne ilişkin algılarında anlamlı farklılıklar ortaya çıkmıştır $(p<.05)$. 'YG $\mathrm{G}_{\text {Duyuşsal', 'YG }}$ Bilişsel', 'YG $\mathrm{G}_{\text {Davranısssal }}$ ' ve 'YG $\mathrm{G}_{\text {toplam }}$ ' boyutlarında; aynı okulda 2-4 yıl arası görev yapan müdürlerle çalışan öğretmenlerin, diğer öğretmenlere göre müdürün yönetsel güçlülüğüne ilişkin algıları daha düşüktür.

\section{Müdürünün Yönetsel Güçlülükleri ve Örgütsel Bağlılıkları Arasındaki İlişki}

Öğretmen algılarına göre müdürlerin örgütsel bağlılıkları ile yönetsel güçlülükleri arasındaki ilişki incelenmiştir (bkz Tablo 15).

Tablo 15. Müdürünün yönetsel güçlülük ve örgütsel bağlılıkları arasındaki ilişki

\begin{tabular}{ccccc}
\hline & $\bar{x}$ & Ss & Yönetsel Güçlülük & Örgütsel Bağlllık \\
\hline Yönetsel Güçlülük & 3.74 & .66 & 1 & \\
Örgütsel Bağlılık & 3.26 & .52 & .797 & 1 \\
\hline
\end{tabular}

Yapılan Pearson korelasyon analizi sonucunda müdürlerin örgütsel bağl1lıkları ile yönetsel güçlülükleri arasında pozitif yönde anlamlı ilişki bulunmuştur ( $r=.797, p<.05)$. Tablo 16'da ise, 
öğretmen algılarına göre müdürlerin örgütsel bağll1ıklarının alt boyutları ile yönetsel güçlülüğünün alt boyutları arasındaki ilişki verilmiştir (bkz Tablo 16).

Tablo 16. Değişkenler arası korelasyonlar $(\mathrm{n}=341)$

\begin{tabular}{ccccccccc}
\hline Değiškenler & $\bar{x}$ & Ss & Duyuşsal & Bilişsel & Davranışsal & Uyum & Özdeşleşme & İ̧selleştirme \\
\hline Yönetsel & & & & & & & & \\
Güçlülük & & & & & & & & \\
\hline Duyuşsal & 3.59 & .62 & 1 & .91 & .88 & .47 & .70 & .68 \\
Bilişsel & 3.84 & .72 & & 1 & .94 & .47 & .73 & .73 \\
Davranişsal & 3.79 & .70 & & & 1 & .47 & .73 & .73 \\
\hline Örgütsel Bağlllık & & & & & & & & \\
\hline Uyum & 3.68 & .40 & & & & 1 & .42 & .39 \\
Özdeşleşme & 2.99 & .69 & & & & & 1 & .82 \\
İsselleştirme & 3.15 & .67 & & & & & & 1 \\
\hline
\end{tabular}

Buna göre duyuşsal ve bilişsel güçlülük arasında çok yüksek ( .91); duyuşsal ve davranışsal güçlülük arasında yüksek (.88); bilişsel ve davranışsal güçlülük arasında pozitif yönde çok yüksek düzeyde ( .94) anlamlı ilişki bulunmuştur. Öğretmenlerin algılarına göre müdürlerin bilişsel $(\bar{x}=3.84)$ ve davranışsal $(\bar{x}$ = 3.79) güçlülükleri, uyum $(\bar{x}=3.68)$ bağlılıkları daha yüksek bulunmuştur. Buna göre, tüm değişkenler arasında pozitif yönde bir ilişki ortaya çıkmıştır. Duyuşsal güçlülük ile uyum $(r=.47, p<.05)$, özdeşleşme $(r=.70, p<.05)$ ve içselleştirmede $(r=.68, p<.05)$ orta; bilişsel güçlülük ile uyumda $(r=$ $.47, p<.05)$ orta, özdeşleşme $(r=.73, p<.05)$ ve içselleştirmede $(r=.73, p<.05)$ yüksek; davranışsal güçlülük ile uyumda $(r=.47, p<.05)$ orta, özdeşleşme $(r=.73, p<.05)$ ve içselleştirmede $(r=.73, p<$ .05) yüksek düzeyde anlamlı ilişki bulunmuştur.

\section{Müdürlerinin Örgütsel Bağlılıklarının Yönetsel Güçlülüklerini Yordama Düzeyleri}

Müdürülerin örgütsel bağlılıklarının yönetsel güçlülük boyutlarının anlamlı yordayıcıları olup olmadığına ilişkin regresyon analizi sonuçları Tablo 17'de verilmiştir. 
Tablo 17. Müdürün yönetsel güçlülüğün ve boyutlarının yordanmasına ilişkin regresyon analizi

\begin{tabular}{|c|c|c|c|c|c|c|}
\hline \multirow{6}{*}{ 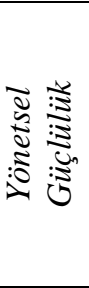 } & Değişken & $B$ & $\begin{array}{c}\text { Standart } \\
\text { Hata }\end{array}$ & $\beta$ & $t$ & $P$ \\
\hline & Sabit & .402 & .204 & & 1.964 & .050 \\
\hline & Uyum & .314 & .061 & .189 & 5.187 & .000 \\
\hline & Özdeşleşme & .359 & .057 & .373 & 6.269 & .000 \\
\hline & İçselleştirme & .353 & .058 & .358 & 6.089 & .000 \\
\hline & $R=.798 R^{2}=.63$ & $000 \mathrm{~F}$ & & & & \\
\hline \multirow{6}{*}{ 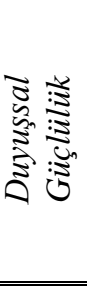 } & Değişken & $B$ & $\begin{array}{c}\text { Standart } \\
\text { Hata }\end{array}$ & $\bar{\beta}$ & $t$ & $P$ \\
\hline & Sabit & .536 & .211 & & 2.548 & .011 \\
\hline & Uyum & .321 & .062 & .205 & 5.145 & .000 \\
\hline & Özdeşleşme & .337 & .059 & .373 & 5.716 & .000 \\
\hline & İçselleştirme & .275 & .060 & .296 & 4.596 & .000 \\
\hline & $R=.751 R^{2}=.56$ & $000 \mathrm{~F}$ & $45\left(Y G_{\text {Duyu }}\right.$ & & & \\
\hline \multirow{6}{*}{  } & Değişken & $B$ & $\begin{array}{c}\text { Standart } \\
\text { Hata }\end{array}$ & $\beta$ & $t$ & $P$ \\
\hline & Sabit & .337 & .228 & & 1.481 & .140 \\
\hline & Uyum & .317 & .067 & .176 & 4.656 & .000 \\
\hline & Özdeşleşme & .381 & .064 & .366 & 5.977 & .000 \\
\hline & İçselleştirme & .381 & .065 & .357 & 5.896 & .000 \\
\hline & $R=.784 R^{2}=.61$ & $000 \mathrm{~F}$ & $33\left(Y G_{\text {Bilisss }}\right.$ & & & \\
\hline \multirow{6}{*}{ 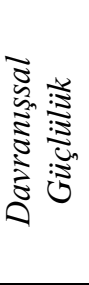 } & Değişken & $B$ & $\begin{array}{c}\text { Standart } \\
\text { Hata }\end{array}$ & $\beta$ & $t$ & $P$ \\
\hline & Sabit & .343 & .221 & & 1.548 & .123 \\
\hline & Uyum & .305 & .066 & .173 & 4.656 & .000 \\
\hline & Özdeşleşme & .358 & .062 & .351 & 5.770 & .000 \\
\hline & İçselleştirme & .398 & .063 & .380 & 6.324 & .000 \\
\hline & $R=.788 R^{2}=.62$ & $000 \mathrm{~F}$ & $36\left(Y G_{\text {Davr }}\right.$ & & & \\
\hline
\end{tabular}

Tablo 17'deki t değerleri ve Standardize edilmiş $\beta$ katsayısı incelendiğinde göreli önem düzeyine göre sırasıyla özdeşleşme, içselleştirme ve uyumun; yönetsel güçlülüğün anlamlı bir yordayıcısı olduğu söylenebilir ( $R=.798 R^{2}=.637$ ). Uyum, içselleştirme ve özdeşleşme yönetsel güçlülükteki toplam varyansın \%64'ünü açıklamaktadır. Standardize edilmiş regresyon katsayılarına göre örgütsel bağlılık boyutlarının yönetsel güçlülük üzerindeki göreli önem sıraları özdeşleşme $(\beta=.373)$, içselleştirme $(\beta=$ .358) ve uyum $(\beta=.189)$ şeklindedir. Regresyon katsayılarının anlamlılığına ilişkin t testi sonuçlarına göre, özdeşleşme $(t=6.269, p<.05)$, içselleştirme $(t=6.089, p<.05)$ ve uyumun $(t=5.187, p<.05)$ müdürün yönetsel güçlülüğü üzerinde anlamlı yordayıcılar olduğu görülmektedir.

Uyum, içselleştirme ve özdeşleşme duyuşsal güçlülükteki toplam varyansın \%56'sını açıklamaktadır. Standardize edilmiş regresyon katsayılarına göre örgütsel bağlılık boyutlarının duyuşsal güçlülük üzerindeki göreli önem sıraları özdeşleşme $(\beta=.373)$, içselleştirme $(\beta=.296)$ ve uyum $(\beta=.205)$ şeklinde olmuştur. Regresyon katsayılarının anlamlılığına ilişkin t-testi sonuçları incelendiğinde, özdeşleşme $(t=5.716, p<.05)$, uyum $(t=5.145, p<.05)$ ve içselleştirmenin $(t=4.596, p<.05)$ müdürün duyuşsal güçlülüğü üzerinde anlamlı yordayıcılar olduğu görülmektedir.

Uyum, içselleştirme ve özdeşleşme bilişsel güçlülükteki varyansın \%61'ini açıklamaktadır. Standardize edilmiş regresyon katsayılarına göre örgütsel bağlılık boyutlarının bilişsel güçlülük üzerindeki göreli önem sıraları özdeşleşme $(\beta=.366)$, içselleştirme $(\beta=.357)$ ve uyum $(\beta=.176)$ 
şeklinde olmuştur. Regresyon katsayılarının anlamlılığına ilişkin t-testi sonuçları incelendiğinde, özdeşleşme $(t=5.977, p<.05)$, içselleştirme $(t=5.896, p<.05)$ ve uyumun $(t=4.656, p<.05)$ müdürün bilişsel güçlülüğü üzerinde anlamlı yordayıcılar olduğu görülmektedir.

$\mathrm{Bu}$ yordayıcı değişkenler davranışsal güçlülükteki varyansın \% 62’sini açıklamaktadır. Standardize edilmiş regresyon katsayılarına göre örgütsel bağlılık boyutlarının davranışsal güçlülük üzerindeki göreli önem sıraları içselleştirme $(\beta=.380)$, özdeşleşme $(\beta=.351)$ ve uyum $(\beta=.173)$ şeklinde olmuştur. Regresyon katsayılarının anlamlılığına ilişkin t-testi sonuçları incelendiğinde, içselleştirme $(t=6.324, p<$ $.05)$, özdeşleşme $(t=5.770, p<.05)$ ve uyumun $(t=4.656, p<.05)$ müdürün davranışsal güçlülüğü üzerinde anlamlı yordayıcılar olmuşlardır.

\section{Tartışma, Sonuç ve Öneriler}

$\mathrm{Bu}$ bölümde araştırmanın alt problemleri ve bulguları doğrultusunda sonuçlar, alanyazın dikkate alınarak tartışılmış ve sonuçlar doğrultusunda önerilere yer verilmiştir.

\section{Yönetsel güçlülük ve boyutların düzeyleri}

Araştırma sonuçları, öğretmen algılarına göre müdürlerin duyuşsal, bilişsel, davranışsal ve toplam yönetsel güçlülük düzeylerinin yüksek olduğunu göstermektedir. Ayrıca öğretmenler; müdürlerinin sırasıyla bilişsel, davranışsal ve duyuşsal güçlülüğe yüksek düzeyde sahip olduklarını düşünmektedirler. Sacır (1978) ise kız meslek lisesi müdürlerinin yönetsel yeterliliklerinin "orta" düzeyde olduğunu bulmuştur. Sacır (1978) zamanla okul müdürlerinin yönetim becerilerinin arttı̆̆ını söylemektedir. Özdere (2015) çalışmasında öğretmen algılarına göre müdürlerin yeterlilik düzeylerinin iyi olduğunu ifade etmektedir. Kanungo ve Menon’a (2004, 2005) göre yönetsel güçlülüğün yüksek olması, müdürlerin yönetimsel rollerini ve işlerini gerçekleştirirken duygu, düşünce ve davranışlarını kontrol etme ve düzenleme becerisine sahip olduklarını göstermektedir. Bu durum, yönetsel güçlülükleri yüksek müdürlerin sağlıklı, etkili ve başarılı okul kültürlerinin oluşmasında önemli olduğunu göstermektedir.

Dağlı'nın (2000) sonuçlarında benzer şekilde, okul müdürlerinin planlı çalışan kişiler olduğu görülmektedir. Korkmaz (2006) da müdürlerin duygusal davranmaktan çok, sorumluluk sahibi bireyler gibi davranarak planlı ve programlı çalışan kişiler olduklarını belirtmektedir. Buna göre, öğretmenlerin okullarının belli kurallarının olduğu; kimin neyi, nerede ve ne zaman yapacağının ve bireylerin yaptırımların belli olduğu düşünülebilir. Örgütte planlamaların olması tahmin edilebilirliği sağlayıp değişkenliği azaltmakta ve eşgüdümlemeye katkıda bulunmaktadır (Hage ve Aiken, 1970).

Öğretmenlere göre, okul müdürleri iyi dinleyicidirler. Yavuz (2010) da müdürlerin yeterli düzeyde dinleme becerisine sahip olduklarını vurgulamaktadır. Trevino, Brown ve Hartman'ın (2003) etik liderlik kavramında iyi bir dinleyici olmak büyük önem taşımaktadır. Okullarda demokratik ortamların yaratılması ve hedeflere etkin olarak ulaşılabilmesi, öğretmen ve müdürlerin çift yönlü iletişimlerinin niteliğiyle ilişkilidir (Şimşek ve Altınkurt, 2009). Okul müdürleri bu durumu göz önünde bulundurmalıdır. Baransel'in (1979) neo-klasik yönetim yaklaşımına göre, örgütler sosyal sistemler oldukları için bireylerarası ilişkiler önem taşır ve düzenlidir. Bireylerarası ilişkilerin örgütsel etkililik üzerinde rolü vardır. 
Öğretmenlere göre, müdürler bir problemle karşılaştıklarında o durumla başedebileceğinden emin kişilerdir. Öğretmenler müdürlerinin karar verme ve problem çözme konularında başarılı olduklarını düşünmektedir. Yukl'a (1981) göre, etkili liderlerde bulunması gereken özelliklerde özgüven sahibi olmak vardır. Dönüşümcü liderlik özellikleri gösteren okul müdürleri kendi kapasite ve yeteneklerine güvenen, özgüven sahibi kişilerdir (Morton, Barling, Rhodes, Masse, Zumbo ve Beauchamp, 2011). Özgüven sahibi okul müdürlerinin öğretmenlere, diğer personellere, öğrenci ve velilere ilham vererek onların performanslarını arttırabilecekleri ve onları takım çalışmasına katabilecekleri söylenebilir.

Öğretmenlere göre, müdürler başarısız olmaktan korkmayan bir yapıya sahiptirler. Oysa yönetsel güçlülüğü yüksek müdürlerin başarısız olmaktan korkmaları beklenmektedir (Kanungo ve Menon, 2005). Bass ve Avolio’nun (1985) sürdürümcü liderleri de başarısızlıktan korkan kişilerdir. Bu durumun oluşmasında, müdürlerin karşılarına çıkan problemlerle ilgili yeterli bilgiye sahip olmamaları ve fazla özgüven sahibi olmalarının etkili olduğu düşünülebilir.

Öğretmenlere göre, müdürler nadiren zor ve belirgin hedefler belirlemektedirler. Oysaki zor ve belirgin hedeflerin daha başarılı işlerin gerçekleşmesini sağlayacağı düşünülmektedir (Kanungo ve Menon, 2005). Amacın zorluğu ve belirginliği güdülenmeyi olumlu etkilemektedir (Getzel ve Guba, 1957). Okul müdürlerinin öğretmenlerin motivasyonlarını arttırabilmeleri için zor, başarılabilir ve belirgin hedefler ortaya koymaları ve bu hedefleri okul kültüründe benimsetmeleri gerektiği söylenebilir. Weber’in (1969) bürokrasi yaklaşımına göre; örgütte her çalışanın yetki ve sorumlulukları belirgin olmalı, kişiler görevleri için belli eğitimler almalı ve bu görev için gerekli becerilere sahip olmalıdır. Araştırmanın sonuçlarına göre müdürlerin hedef belirleme konusunda eksikliklerinin olduğu düşünülebilir.

Öğretmenlere göre, müdürler işlerin bitirilmesiyle kıyaslandığında zaman konusunda daha az hassastırlar. Drucker (1974) ise, zaman doğru yönetilmiyorsa hiçbir şeyin doğru yönetilemeyeceğini ifade etmektedir. Bir başka deyişle, okul müdürlerinin zaman yönetimi konusunda becerilerinin üst düzeyde olması beklenmektedir. Ö̆ğretmenlerin, müdürlerin yönetsel güçlülüklerine ilişkin algıları onların cinsiyetinden etkilenmemektedir. Benzer şekilde, Özdere (2015) ve Terci (2008) çalışmalarında okul yöneticilerinin yönetsel yeterliklerine ilişkin öğretmen algılarının; öğretmenlerin cinsiyetlerine göre farklılık göstermediğini belirtmektedirler. Farklı olarak Demircan (2001), erkek öğretmenlerin ilköğretim okul müdürlerinin yönetici yeterliliklerine ilişkin algılarının daha yüksek olduğunu, Asar (2014) ise, kadın öğretmenlerin yöneticilerin iletişim becerilerine ilişkin algılarının erkeklerden daha yüksek olduğunu vurgulamaktadır. $\mathrm{Bu}$ araştırmalar arasındaki farklılıkların, kullanılan ölçme araçlarının, araştırmanın uygulandığı örneklemin, okul bulunduğu çevrenin farklı olmasından kaynaklanmış olabileceği düşünülebilir.

Öğretmenlerin, müdürlerin yönetsel güçlülüklerine ve boyutlara ilişkin algıları onların kıdemlerinden etkilenmemektedir. Karaman (2008) ve Asar (2014) da, farklı kıdemlerdeki öğretmenlerin müdürlerin göstermiş olduğu yöneticilik davranışlarına ilişkin algılarının benzer olduğunu ifade etmektedir. Öğretmenlerin, müdürlerin yönetsel güçlülüklerine ilişkin algıları onların branşlarından 
etkilenmemektedir. Bu bulgu Özdere (2015), Göl ve Bülbül (2012) ve Terci’nin (2008) bulgular1 ile örtüşmektedir.

41-60 arası öğretmenin bulunduğu okullardaki öğretmenlerin, 21-40 arası ve 61 ve üzeri öğretmenin bulunduğu okullardaki öğretmenlere göre okul müdürünün yönetsel güçlülüğüne ve duyuşsal güçlülüğüne ilişkin algıları daha düşüktür. 41-60 arası öğretmenin bulunduğu okullardaki öğretmenlerin, diğer öğretmenlere göre müdürün bilişsel ve davranışsal güçlülüğüne ilişkin algıları daha düşüktür. Okuldaki öğretmen sayısı 40’tan fazla olan okullardaki öğrenci mevcutları oldukça çoktur. Öğretmen sayısı arttığında daha çok yönetsel zorlukla, sorunla ve çatışmalarla karşılaşıldığı düşünülebilir. Öğretmen sayısının 60’tan fazla olduğu okullarda en az 3 müdür yardımcısının müdürün yönetsel işlerine yardım ettiği görülmüştür. 41-60 arası öğretmene sahip okullarda ise genellikle 2 müdür yardımcısı vardır ve bu durum müdürün yönetsel işlerini çözmesini zorlaştırmaktadır. 41-60 arası öğretmene sahip okullardaki öğretmenlerin, okul müdürün yönetsel güçlülüğüne ilişkin algılarının bu bakımdan düşük olduğu düşünülebilir. Farklı olarak, Özdere (2015) çalışmasında 40-59 öğretmeni bulunan okullardaki öğretmenlerin müdürlerin yeterliliklerine ilişkin algılarının diğerlerine göre daha yüksek olduğunu ifade etmekte ve okullardaki öğretmen sayısının okul müdürlerinin yeterlilik alt boyutlarının tamamında anlamlı farklılıklar yarattığını söylemektedir.

Çalışmada 500’den daha az öğrenciye sahip okullardaki öğretmenlerin müdürlerin bilişsel, davranışsal ve toplam yönetsel güçlülüğüne ilişkin daha yüksek bir algıya sahip oldukları görülmektedir. 500-1000 arası öğrenciye sahip okullarda çalışan öğretmenlerin, müdürlerin duyuşsal güçlülüklerine ilişkin daha düşük bir algıya sahip oldukları görülmektedir. Terci (2008) de, yöneticilerin yeterlik davranışlarına ilişkin 300-500 öğrenci mevcutlu okullarda görev yapan öğretmen algılarının, daha kalabalık okullarda görev yapan öğretmenlerin algılarına göre daha olumlu olduğunu belirtmektedir. Özdere'nin (2015) araştırmasında 501-1000 öğrenci bulunan okullarda müdürlerin yeterliliklerin öğretmenler tarafından daha yüksek algılandığı yönündedir. Karaman (2008), öğrenci sayısının 1001-2000 olan okullardaki öğretmenlerin, müdürlerinin göstermiş olduğu yöneticilik davranışının daha kalabalık okullardakilere göre daha fazla olduğunu belirtmişlerdir. Erdoğan’a (2000) göre örgütün büyüklüğü; amaçların, amaçların gerçekleştirilmesinde kullanılan araç ve yöntemlerin, iletişim sisteminin, denetim sisteminin, görevsel ilişkilerin daha karmaşık bir nitelik kazanmasına neden olabilir. Küçük okullardaki öğretmenlerin daha büyük okullardaki öğretmenlere göre yönetici yeterlik davranışlarına ilişkin daha olumlu bir algıya sahip oldukları görülmektedir. Bu sonucu iki yönden değerlendirebiliriz. Küçük okullarda iletişim, yönetim ve denetimin daha rahat ve sağlıklı işlemesinden dolayı yöneticilerin kontrol ve yaptırım güçleri daha yüksektir; bunun sonucunda yöneticilerin yeterlik davranışlarının daha olumlu algılandığını söyleyebiliriz. Diğeri ise, öğrenci sayısının az olması ile kalitenin yükselmesi arasında ilişki kurulabilir. Öğrenci sayısı fazla olan okullarda; yöneticilerin örgütün amaçlarının gerçekleştirilmesine, kendilerinin ve kurumlarının gelişimine, denetime, insan kaynaklarına daha az zaman ayırmak durumunda kalabileceği ve daha karmaşık ama sağlıksız bir iletişim ortamının oluşabileceği söylenebilir. Bu doğrultuda araştırmaya katılan öğretmenlerin; öğrenci mevcudu daha az olan okullardaki müdürlerin yeterlik davranışlarına ilişkin daha olumlu algıya sahip olduklarını söyleyebiliriz. Okullardaki öğrenci 
sayısının azlığı müdürlerin yüklerini hafiflettiği gibi, karmaşık durumlarla karşı karşıya kalma durumlarını da azaltmaktadır. Bu durumda müdürlerin yönetsel güçlülüklerinin çok üst düzeyde olması beklentisini düşürerek öğretmen algılarının yüksek olmasına sebep olduğu düşünülebilir.

Araştırmada 2 müdür yardımcısına sahip okullarda görev yapan öğretmenlerin okul müdürünün yönetsel güçlülüğüne ilişkin daha düşük bir algıya sahip olduğu bulunmuştur. Özdere (2015) çalışmasında en az 4 idarecisi bulunan okullarda müdürlerin daha yüksek yeterlilik sergilediklerini bulmuştur. Yürürlükteki mevzuata göre okullardaki idareci sayısı öğrenci sayılarına göre planlanmaktadır. Oysaki idarecilerin sorumlulukları öğrenci işlerinden ibaret değildir ve zaman zaman projelerde görev almak üzere yabancı dil, çeşitli araştırma geliştirme faaliyetlerinde yeterlik sağlamak üzere raporlama vb. gibi farklı yeterlikler ve her biri için ekstra zaman gerektiren birçok bürokratik işlemi de kapsamaktadır. 2 müdür yardımcısının olduğu okullar öğrenci sayılarının 500-1000 arası olduğu okullar olarak düşünüldüğünde, öğretmen algılarına göre yönetsel işlerin 2 müdür yardımcısıyla yürütülmesinde zorluklar yaşandığı ve müdür yardımcısı sayısının 3 veya daha fazla olması gerektiği düşünülebilir. Ya da tek müdür yardımcısıyla idare edilebilecek kadar az öğrenci kapasitesine sahip okullarda okul müdürlerinin karşılaştıkları yönetsel sorunların daha çözülebilir nitelikte olduğu düşünülebilir. Müdürün aynı okulda dört yıldan fazla görev aldığı ortaokullardaki öğretmenlerin, müdürün yönetsel güçlülüğüne ilişkin algıları diğer öğretmenlerin algılarından daha yüksektir. Buna göre, müdürlerin okuldaki görev süreleri arttıkça okulun sorunlarına ilişkin daha deneyimli ve bilgili oldukları ve bu sayede yönetsel güçlülük düzeylerinin daha yüksek çıktığı söylenebilir.

\section{Öğretmenlerin, Müdürlerin Yönetsel Güçlülükleri ile Örgütsel Bağlılıları Arasındaki İlişkiye Yönelik Algıları}

Çalışmada, müdürlerin örgütsel bağlılıkları ile yönetsel güçlülükleri arasında pozitif yüksek düzeyde anlamlı ilişki olduğu belirlenmiştir. Müdürlerin yönetsel güçlülüklerinin artması örgütsel bağlılıklarının artmasını sağlıyorsa bu durum okul ikliminin de olumlu bir atmosfer kazanmasına katkıda bulunabilir. Yönetsel güçlülüğe sahip okul müdürlerinin okulda yaşanan sorunlarla başetmede, kriz durumlarını yönetmede daha başarılı oldukları düşünülebilir. Çünkü bu kişiler duygusal, bilişsel ve davranışsal anlamda güçlü olup, ne yapılması gerektiğine doğru karar verebilen kişiler oldukları söylenebilir. Okul müdürlerinin yönetsel güçlülüklerinin okul iklimini etkileyeceği düşünülmektedir. Okul ikliminde etkili olan faktörleri iki ana başlıkta toplamak mümkündür. Bunlar müdürden kaynaklı faktörler (denetim, yakınlık, anlayış gösterme ve teşvik) ve öğretmenden kaynaklı faktörlerdir (rutin işlerle engellemek, mahremiyet, ilgisizlik ve moral) (Hoy ve Miskel, 1978). Yönetsel güçlülüğe sahip okul müdürünün kendinden kaynaklı faktörlerin olumlu olmasında; öğretmenden kaynaklı faktörlerin ise dolaylı olarak olumlu olmasında etkili olacağı düşünülebilir. Olumlu bir iklime sahip okullarda ise işgörenlerin işte çalışma isteklerinin daha fazla olduğu söylenebilir. Kısaca, okul müdürlerinin yönetsel güçlülüğe sahip olmasının olumlu bir iklim oluşturduğu, bu olumlu iklime bağlı olarak müdürlerin okula bağlılığının arttığı söylenebilir. Kaya, Balay ve Tınaz (2014)’ın ilk/ortaokullardaki yönetici ve öğretmenlerin örgütsel bağlılıkları ve yönetsel etkililikleri arasındaki ilişkiyi açıkladığı çalışmasında pozitif orta düzeyde anlamlı 
bir ilişki belirlenmiştir. Buna göre, okul kültüründeki müdürlerin örgütsel bağlılıklarının yüksek olması durumunda okuldaki yönetimsel anlamda etkililiklerinin arttığı söylenebilir.

Araştırmanın bulgularına göre, örgütsel bağlılığın alt boyutları (uyum, özdeşleşme ve içselleştirme) yönetsel güçlülüğün anlamlı bir yordayıcısıdır. Müdürlerinin yönetimsel anlamdaki güçlülükleri değerlendirilirken örgütsel bağlılıkları da göz önünde bulundurulabilir. Özellikle özdeşleşme ve içselleştirme bağlılığı yüksekokul müdürlerinin yönetimsel anlamda da daha güçlü olabilecekleri düşünülebilir. Okul ikliminin örgütsel bağlılık üzerinde etkili bir faktör olduğu düşünüldüğünde; Karataş (2008) müdürlerin etkililiği ve okul iklimi ilişkisini incelediği çalışmasında, müdürlerin yönetsel becerileriyle okul ikliminin boyutları (moral, samimiyet, yakından kontrol, işe dönüklük ve anlayış gösterme) arasında pozitif ilişki belirlemiştir.

\section{Araştırmacılara Yönelik Öneriler}

Sonraki çalışmalarda, farklı okul düzeylerinde (lise, ilkokul, vs) ve okul kültürlerinde (sınav başarıları, ekonomik düzeyleri,vs farklı okullar) görev yapan müdürlerin yönetsel güçlülüklerine ilişkin karma araştırmalar gerçekleştirilebilir. Okul müdürlerinin yönetimsel anlamda daha güçlü olmalarını sağlamak veya örgütsel bağlılıklarını arttırmak adına hizmetiçi eğitimler düzenlenebilir. Okul müdürünün yönetsel güçlülüğü çok düşük ve çok yüksek çıkan okullarda bu durumun nedenine ilişkin nitel durum çalışmaları veya karma araştırmalar yürütülebilir. Yönetsel güçlülük kavramına ilişkin kuramsal araştırmalarla bu kavrama ilişkin daha derin ve farklı görüşler açığa çıkarılabilir. Özellikle Denizli'de 2 müdür yardımcısı olan, 500-1000 öğrenciye sahip okullarda öğretmenlerin; müdürlerinin yönetsel güçlülüğüne ilişkin algıları düşüktür. Buna neden olabilecek birçok faktör bu tür okullarda yapılacak ayrıntılı nitel araştırmalarla ortaya koyulmalıdır. Örgütsel bağlılık, yönetsel güçlülüğün oldukça yüksek bir yordayıcısıdır, müdürlerin yönetsel güçlülüklerini yordayan diğer faktörler araştırılabilir.

\section{Uygulayıcılara Yönelik Öneriler}

Elde edilen sonuçlar incelendiğinde, mevcut okul sayısı arttırılıp okul başına düşen öğrenci sayısı azaltılarak daha etkili okullar oluşturulabilir. Kalabalık okulların karmaşık yapısı özellikle yöneticilerin yönetsel güçlülüklerinin iyi olmasını gerektirir. Bu nedenle büyük örgütlerde yöneticilerin özenli şekilde seçilmesi gerekmektedir. Okuldaki müdür yardımcısı sayısı 2 olduğunda, öğretmenler müdürlerin yönetsel güçlülüklerini daha yetersiz bulmaktadır. Bu anlamda 500-1000 öğrenciye ve 2 müdür yardımcısına sahip okullarda öğrenci sayısı azaltılarak tek müdür yardımcısı ile veya bu okullarda en az 3 müdür yardımcısı ile müdürlerin yönetsel anlamda daha güçlü olmalarına fırsat verilebilir. Ayrıca okul kültürünün tüm bileşenleri elde edilen sonuçlarla ilgili bilgilendirilebilir ve müdür seçme koşulları düşünüldüğünde müdürlerin yönetsel güçlülük becerileri dikkate alınabilir. Hizmetiçi eğitimlerle belirgin ve zor hedefler konusunda müdürler bilgilendirilebilir ve kendilerini geliştirmeleri sağlanabilir. Ayrıca araştırma göstermiştir ki örgütsel bağlılık yönetsel güçlülüğün anlamlı bir yordayıcısıdır ve bu nedenle müdürlerin yönetsel güçlülüklerinin arttırılması için onların örgütsel bağlılıklarını da arttırıcı önlemlerin alınabilir. 


\section{Kaynakça}

Allen, N. J. \& Meyer, J. P. (1990). The measurement and antecedents of affective, contunuance and normative commitment to the organizations. Journal of Occupational Pyschology, 63, 1-18.

Asar, R. (2014). Eğitim kurumlarında kadın yöneticilere karşı tutumların değerlendirilmesi. Yayımlanmamış yüksek lisans tezi, Erciyes Üniversitesi, Eğitim Bilimleri Enstitüsü, Kayseri.

Aslan, H. (2006). Ortaöğretim kurumlarında görev yapan öğretmenlerin öğrenilmiş güçlülük düzeyleri ve cinsiyetlerine göre mizah tarzlarının incelenmesi. Yayınlanmamış yüksek lisans tezi, Çukurova Üniversitesi, Sosyal Bilimler Enstitüsü, Adana.

Balay, R. (2000). Özel ve resmi liselerde yönetici ve öğretmenlerin örgütsel bağlllı̆̆l (Ankara ili örneği). Yayımlanmamış doktora tezi, Ankara Üniversitesi, Sosyal Bilimler Enstitüsü, Ankara.

Baransel, A. (1979). Çağdaş yönetim düşüncesinin evrimi: Klasik ve neo-klasik yönetim ve örgüt teorileri - Cilt 1. İstanbul: İstanbul Üniversitesi.

Bass, B. M. \& Avolio, B. (1995). MLQ-Multifactor leadership questionnaire. Mind Garden, Palo Alto, California.

Bursalığlu, Z. (1982). Eğitim yönetiminde yeni yapı ve davranış. Ankara: Eğitim Bilimleri Fakültesi Yayınlar1.

Büyüköztürk, Ş., Kılıç Çakmak, E., Akgün, Ö. E., Karadeniz, Ş. ve Demirel, F. (2014). Bilimsel araştırma yöntemleri. Ankara: Pegem Akademi.

Cook, M.D. (2008). Exploring the impact of management functions on indigeneous policy. Unpublished Doctoral Dissertasion. North Central University, ABD.

Çelik, V. (2000). Okul kültürü ve yönetim. Ankara: Pegem A Yayıncılık.

Dağ, İ. (1991). Rosenbaum’un Öğrenilmiş Güçlülük Ölçeğinin üniversite öğrencileri için güvenilirliği ve geçerliliği. Türk Psikiyatri Dergisi, 2(4), 269-274.

Dağl1, A. (2000). Illköğretim öğretmenlerinin algllarına göre ilköğretim müdürlerinin etkili müdürlük davranışları. Yayımlanmamış yüksek lisans tezi, Hacettepe Üniversitesi Sosyal Bilimler Enstitüsü, Ankara.

Demircan, A. (2001). İlköğretim okulu müdürleri yöneticilik yeterliklerine ne derece sahiptirler?. Yayınlanmamış yüksek lisans tezi, Yıldız Teknik Üniversitesi Sosyal Bilimler Enstitüsü, İstanbul.

Doğan, S. ve Şahin, F. (2011). Yönetsel güçlülük ve etkililik: Kavramsal bir çalışma. Atatürk Üniversitesi İktisadi ve İdari Bilimler Dergisi, 25(2), 61-85.

Drucker, P. F. (1974). Management: Tasks, responsibilities, practices. New York, USA: Harper \& Row.

Erdoğan, İ. (2000). Okul yönetimi ve öğretim liderliği. İstanbul: Sistem.

Etzioni, A. A. (1961). Comparative analysis of complex organization. NY: Free Press. 
Frese, M., Stewart, J. \& Hannover, B. (1987). Goal orientation and planfulness: Action styles as personality concepts. Journal of Personality and Social Psychology, 52(6), 1182-1194.

Gay, L. R. \& Airasian, P. (1996). Educational research: Competencies for analysis and application (6th edition). Upper Saddle River, NJ: Merrill/Prentice Hall.

Getzels, J. W. \& Guba, E. G. (1957). Social behavior and the administrative process. School Review, 65, 423-41.

Goleman, D. (2005). Duygusal zekâ, 29. Bask1, (Çev. Banu Seçkin Yüksel). İstanbul: Varlık.

Göl, E. ve Bülbül, T. (2012). İlköğretim okulu yöneticilerinin yenilik yönetimi yeterliklerine ilişkin öğretmen algıları. Mersin Üniversitesi Ĕ̈itim Fakültesi Dergisi, 8(2), 97-109.

Grusky, O. (1966). Career mobility and organizational commitment. Administrative Science Quarterly, 10(4), 488-503.

Heppner, P. P. (1978). A review of the problem solving literature and its relationships to the counseling process. Journal of Counseling Psychology, 25(5), 366-375.

Heppner, P. P. \& Krauskopf, C. J. (1987). An infromation processing apporach to personal problem solving. The Counseling Psychologist, 15, 371-447.

Herzberg, F. W. (1959). The motivation to work. New York: John Willey.

Hicks, H. G. (1977). Örgütlerin yönetimi: Sistemler ve beşeri kaynaklar açısından. Ankara: San Matbaası.

Hoy, W. H. \& Miskel, C. G. (1978). Educational administration: Theory, research, and practice. New York: Random House.

Kanungo, R. N. \& Menon, S. T. (2004). Managerial resourcefulness: The construct and its measurement. The Journal of Entrepreneurship, 13(2), 129-152.

Kanungo, R. N. \& Menon, S. T. (2005). Managerial resourcefulness: Measuring a critical component of leadership effectiveness. The Journal of Entrepreneurship, 14(1), 39-55.

Kanungo, R. N. \& Misra, S. (1992). Managerial resourcefulness: A reconceptualization of management skills. Human Relations, 45(2), 1311-1332.

Karaman, F. (2008). Ortaöğretim okullarında görev yapan okul müdürlerinin göstermiş olduğu liderlik ve etkili yöneticilik davranışları. Yaımlanmamış yüksek lisans tezi, Beykent Üniversitesi, İstanbul.

Karasar, N. (1998). Bilimsel araştırma yöntemi. Ankara: Nobel.

Karataş, S. (2008). Okul müdürlerinin etkililiği ve okul iklimi (Ístanbul Fatih ve Eminönü ilçeleri örneği). Yayımlanmamış yüksek lisans tezi. Yeditepe Üniversitesi Sosyal Bilimler Enstitüsü, İstanbul. 
Kaya, A., Balay, R. ve Tınaz, S. (2014). Yönetici ve öğretmenlerin yönetsel etkililik ve örgütsel bağlılık algıları arasındaki ilişki. Ahi Evran Üniversitesi Kırşehir Ĕgitim Fakültesi Dergisi (KEFAD), 15(2), 79-97.

Korkmaz, M. (2006). Okul yöneticilerinin kişilik özellikleri ile liderlik stilleri arasındaki ilişki. Kuram ve Uygulamada Ĕ̌itim Yönetimi, 46, 199-226.

Mayer, J. D., DiPaolo, M., \& Salovey, P. (1990). Perceiving affective content in ambiguous visual stimuli: A component of emotional intelligence. Journal of Personality Assessment, 54(3\&4), 772781.

Morton, K.L., Barling, J. Rhodes, R. E. Mâsse, L. C., Zumbo, B. D., \& Beauchamp, M.R. (2011). The application of transformational leadership theory to parenting: questionnaire development and 1mplications for adolescent selfregulatory efficacy and life satisfaction. Journal of Sport and Exercise Psychology, 33, 688-709.

O’Reilly, C. A. \& Chatman, J. (1986). Organizational commitment and pyschological attachment: the effects of compliance, identification and internalization on prosocial bahavior. Journal of Applied Psychology, 71(3), 492-499.

Özdere, Z. (2015). Öğretmen algllarına göre okul müdürlerinin yeterlilik düzeyleri ile örgütsel güven düzeyi arasindaki ilişkinin incelenmesi (Beykoz ilçesi örneği). Yayımlanmış yüksek lisans tezi. Yeditepe Üniversitesi, İstanbul.

Parker, S. K., Williams H. M. ve Turner N. (2006). Modeling the antecedents of proactive behavior at work. Journal of Applied Psychology, 91 (3):636-652.

Sacır, S. (1978). Klz meslek lisesi müdürlerinin yeterlilikleri. Yayınlanmamış doktora tezi. Ankara Üniversitesi Eğitim Fakültesi, Ankara.

Sakallı, N. (2001). Sosyal etkiler: Kim kimi nasıl etkiler?. Ankara: İmge.

Salovey, P. \& Mayer, J. D. (1990). Emotional intelligence. Imagination, Cognition and Personality, 9, 185-211.

Savaşır, I. ve Şahin, N. H. (1997). Bilişsel-Davranış̧̧ı terapilerde değerlendirme: Sık kullanılan ölçekler. Ankara: Türk Psikologlar Derneği Yayını.

Schwarzer, R., Bäßler, J., Kwiatek, P., Schröder, K., \& Zhang, J. Xin (1997). The assessment of optimistic self-beliefs: Comparison of the German, Spanish, and Chinese version of the General SelfEfficacy Scale. Applied Psychology: An International Review, 46 (1): 69-88.

Schyns, B. \& Collani, G. (2002). A new occupational self-efficacy scale and its relation to personality constructs and organizational variables. European Journal of Work and Organizational Psychology, 11(2), 219-241. 
Siva, A. (1991). Infertile'de stresle başetme, ögrenilmiş güçlülük ve depresyonun incelenmesi. Yayınlanmamış doktora tezi, Hacettepe Üniversitesi, Nörolojik ve Psikiyatrik Bilimler Enstitüsü, Ankara.

Staw, B. \& Salancik, G. (1977). New directions in organisational behavior. Chicago, IL: St Clair Press.

Şahin, F. (2009). Yönetsel güçlülük: Etkili liderlik ve yönetim bileşeni olarak kavramsallaştırılması ve ölçülebilmesine ilişkin bir araştırma. Yayımlanmamış doktora tezi, Niğde Üniversitesi Sosyal Bilimler Enstitüsü, Niğde.

Şimşek, Y. ve Altınkurt, Y. (2009). Endüstri meslek liselerinde görev yapan öğretmenlerin okul müdürlerinin iletişim becerilerine ilişkin görüşleri. Uluslararası Hakemli Sosyal Bilimler E-DergisiAkademik Bakış, 17, 1-16.

Terci, F. (2008). İlköğretim okulu yöneticilerinin yönetici yeterlik davranışlarının bazı değişkenler açısından incelenmesi. Yayımlanmamış yüksek lisans tezi. Ege Üniversitesi Sosyal Bilimler Enstitüsü. İzmir.

Treviño L. K., Brown, M., \& Hartman, L. P. (2003) A qualitative 1nvestigation of perceived executive ethical leadership: Perceptions from inside and outside the executive suite. Human Relations, 56(1), 5-37.

Urbanski, J. C. (2000). The relationship of personality constructs to the effects of vie theory judgments on delay of gratification behavior. Unpublished Doctoral Dissertation, South Carolina: University of South Carolina.

Van Brekelen, Q. H. (1996). Facts on factories: In search of manufacturing excelence (Doctoral thesis). Erasmus University, Rotterdam.

Wiener, Y. (1982). Commitment in organization a normative view. Academy of Management Review, 7(3), 418-428.

Yavuz, M. (2010). Adaptation of the leadership practices inventory (LPI) to Turkish. Eğitim ve Bilim Dergisi, 35(158), 143-157.

Yukl, G.A. (1981). Leadership in organizations. U.S.A: Prentice-Hall Inc.

Zeynel, E. ve Çarıkçı, İ. H. (2015). Mesleki motivasyonun, iş tatmini ve örgütsel bağlılık üzerine etkisi: Akademisyenler üzerine görgül bir araştırma. Süleyman Demirel Üniversitesi İktisadi ve İdari Bilimler Fakültesi Dergisi, 20(3), 217-248. 